Article

\title{
Synthesis of a New Phosphonate-Based Sorbent and Characterization of Its Interactions with Lanthanum (III) and Terbium (III)
}

\author{
Yuezhou Wei ${ }^{1,2}{ }^{(D}$, Khalid A. M. Salih ${ }^{1}\left(\mathbb{D}\right.$, Mohammed F. Hamza ${ }^{1,3, *(D)}$, Toyohisa Fujita ${ }^{1}$, \\ Enrique Rodríguez-Castellón ${ }^{4, *(\mathbb{D})}$ and Eric Guibal ${ }^{5}$ (D)
}

\section{check for} updates

Citation: Wei, Y.; Salih, K.A.M.; Hamza, M.F.; Fujita, T.;

Rodríguez-Castellón, E.; Guibal, E. Synthesis of a New

Phosphonate-Based Sorbent and Characterization of Its Interactions with Lanthanum (III) and Terbium (III). Polymers 2021, 13, 1513. https:// doi.org/10.3390/polym13091513

Academic Editor: Melissa Gurgel Adeodato Vieira

Received: 14 April 2021

Accepted: 3 May 2021

Published: 8 May 2021

Publisher's Note: MDPI stays neutral with regard to jurisdictional claims in published maps and institutional affiliations.

Copyright: (c) 2021 by the authors. Licensee MDPI, Basel, Switzerland. This article is an open access article distributed under the terms and conditions of the Creative Commons Attribution (CC BY) license (https:// creativecommons.org/licenses/by/ $4.0 /)$.
1 Guangxi Key Laboratory of Processing for Non-ferrous Metals and Featured Materials, School of Resources, Environment and Materials, Guangxi University, Nanning 530004, China; yzwei@gxu.edu.cn (Y.W.); Immortaltiger7@gmail.com (K.A.M.S.); fujitatoyohisa@gxu.edu.cn (T.F.)

2 Guangdong Institute of Rare Metals, Guangdong Academy of Science, Guangzhou 510651, China

3 Nuclear Materials Authority, El-Maadi, Cairo POB 530, Egypt

4 Departamento de Química Inorgánica, Facultad de Ciencias, Universidad de Málaga, 29016 Málaga, Spain

5 Polymers Composites \& Hybrids (PCH), IMT-Mines Ales, 30100 Alès, France; eric.guibal@mines-ales.fr

* Correspondence: m_fouda21@hotmail.com (M.F.H.); castellon@uma.es (E.R.-C.); Tel.: +20-2-01116681228 (M.F.H.); +34-645263909 (E.R.-C.)

Abstract: High-tech applications require increasing amounts of rare earth elements (REE). Their recovery from low-grade minerals and their recycling from secondary sources (as waste materials) are of critical importance. There is increasing attention paid to the development of new sorbents for REE recovery from dilute solutions. A new generation of composite sorbents based on brown algal biomass (alginate) and polyethylenimine (PEI) was recently developed ( $\mathrm{A}_{\mathrm{L}} \mathrm{PEI}$ hydrogel beads). The phosphorylation of the beads strongly improves the affinity of the sorbents for REEs (such as La and $\mathrm{Tb}$ ): by 4.5 to 6.9 times compared with raw beads. The synthesis procedure (epicholorhydrinactivation, phosphorylation and de-esterification) is investigated by XPS and FTIR for characterizing the grafting route but also for interpreting the binding mechanism (contribution of N-bearing from PEI, O-bearing from alginate and P-bearing groups). Metal ions can be readily eluted using an acidic calcium chloride solution, which regenerates the sorbent: the FTIR spectra are hardly changed after five successive cycles of sorption and desorption. The materials are also characterized by elemental, textural and thermogravimetric analyses. The phosphorylation of $A_{L}$ PEI beads by this new method opens promising perspectives for the recovery of these strategic metals from mild acid solutions (i.e., $\mathrm{pH} \sim 4)$.

Keywords: phosphonate-functionalization; rare earth elements; enhanced sorption capacities; FTIR and XPS characterization; interpretation of binding mechanisms; algal/polyethylenimine beads

\section{Introduction}

The development of high-tech devices causes an increasing demand for rare earth elements (REEs) [1]. This pressure may explain the incentive politics defended by international institutions for recovering these strategic metals from secondary resources such as low-grade minerals [2] and phosphate rocks [3], but also from waste industrial materials [4-6]. Hydrometallurgical processes are commonly used for recovering these metals from solid wastes and ores through acid leaching processes [7-11].

Sorption processes have been widely designed for the recovery of rare earth elements, including functionalized silica [12], carbon-based sorbents [13], chemically modified membranes [14], metal organic framework [15], ion-exchange resins and chelating resins [16,17].

Solvent extraction is a standard process currently employed for the removal of REEs from acidic leachates [18-21], especially for solutions containing high metal concentrations. Most of these highly efficient extractants are based on phosphorus reagents such as 
alkyl phosphate [19,22-26], alkyl phosphoric acid [27-29], alkyl phosphine oxide [30,31], phosphonium ionic liquids [32,33] and organophosphonic extractants [34-37]. The strong affinity of phosphorus-based extractants for rare earth easily explains that a strong effort has been made for designing synthetic resins bearing phosphorus-based reactive groups such as Tulsion CH-96 and T-PAR resins [38,39], Tulsion CH-93 [34], Purolite S957 and Diphonix [40] or metal-organic frameworks [41]. Heres et al. [42] compared a series of resins bearing phosphonic reactive groups (multifunctional resins) for the extraction of REEs from phosphoric acid and they reported that aminophosphonic IRC-747 and aminomethylphosphonic TP-260 resins are the most promising. The chemical environment of phosphonic groups turned out to be particularly important for the sorption performances of this type of resin in the recovery of REEs but also for other metal ions such as U(VI) [43,44].

Recently, a new type of support has been designed based on the one-pot synthesis of a composite associating alginate extracted from brown algae (Laminaria digitata brown alga) and polyethylenimine (PEI). The interpenetrating network created by the interaction between carboxylic acid groups of alginate and amine groups of PEI, completed by the ionotropic gelation of carboxylic groups of alginate with calcium chloride and the crosslinking of amine groups with glutaraldehyde allows producing very stable beads. In some cases, it may be useful to introduce amounts of alginate in the synthesis procedure to increase the stability of the composite. Alginate has been used for incorporating and stabilizing magnetic nanoparticles for the synthesis of composite sorbents, and applied for rare earth elements [45,46]. These materials are multifunctional bearing carboxylic groups and amine groups with a high affinity for a wide range of metal ions (depending on the $\mathrm{pH}$ ): metal anions in acidic solutions and metal cations in near-neutral solutions. The presence of these reactive groups also allows for readily functionalizing the sorbent by activation of amine groups. Hence, a series of sorbents functionalized with amidoxime groups [44], quaternary ammonium groups [47], sulfonic groups [48] and phosphoryl groups [49] have been designed. Studies confirm the contribution of several groups on multifunctional sorbents in the recovery of selected metal ions (uranyl ions, metalloid anions, and members of the REE family).

The current work describes a new derivative of algal/PEI beads $\left(\mathrm{A}_{\mathrm{L}} \mathrm{PEI}\right.$, with addition of alginate) obtained by activating the support by epichlorohydrin grafting, followed by phosphorylation and de-esterification (to make free the phosphonic acid groups, in addition to other reactive functions: carboxylic and amine groups, $\mathrm{POH}-\mathrm{A}_{\mathrm{L}} \mathrm{PEI}$ ). This sorbent is tested for the sorption of two REEs: La (III) (as a representative of light REEs, LREEs) and Tb (III) (heavy REEs, HREEs). This specific part of the study focuses on (a) the characterization of the sorbent (in the different stages of the synthesis procedure), and (b) the identification of the binding mechanisms by spectral analysis: Fourier-transform infrared and X-ray photoelectron spectroscopies. The effect of the $\mathrm{pH}$ is also considered as a complementary contribution to the interpretation of binding mechanism.

\section{Materials and Methods}

\subsection{Materials}

Algal biomass (Laminaria digitata) was kindly supplied by Setalg (Pleubian, France). After grinding, algal biomass was sieved and particles below $250 \mu \mathrm{m}$ were used for preparing the raw beads. Branched polyethylenemine (PEI, 50\%, w/w in water), and glutaraldehyde (GA, 50\%, w/w in water) were supplied by Sigma-Aldrich (Taufkirchen, Germany). Polyethylene glycol diglycidyl ether ( $\mathrm{MW}_{\mathrm{n}}$ : $\sim 500 \mathrm{~g} \mathrm{~mol}^{-1}$ ), triethyl phosphite, epichlorohydrin and trimethylsilyl bromide were purchased by Shanghai Makclin Biochemical Co., Ltd. (Shanghai, China). Dichloromethane was supplied by Xilong Scientific Co., Ltd., (Guangdong, China). Ethanol absolute and sodium hydroxide were purchased from Guangdong Guanghua Sci-Tech (Guangzhou, China). Lanthanum (III) sulfate and terbium (III) sulfate were supplied by National Engineering Research Centre of Rare Earth Metallurgy and Functional Materials Co., Ltd., Shijiazhuang, China. Silicon standard solution (1000 ppm, used as the source for $\mathrm{Si}$ ) was supplied by Guobiao Inspection and Certification Co. Ltd. 
(Huairou District, Beijing, China). The other reagents were Prolabo products (VWR, Radnor, PA, USA).

\subsection{Synthesis of Functionalized Sorbent (POH- $\left.A_{L} P E I\right)$}

\subsubsection{Synthesis of Algal/PEI Beads ( $\left.\mathrm{A}_{\mathrm{L}} \mathrm{PEI}\right)$}

Composite homogeneous algal/PEI beads were prepared by a three-step procedure: (a) partial alginate extraction from algal biomass, (b) mixing with PEI solution and (c) ionotropic gelation. Finally, the beads were freeze-dried $\left(-52^{\circ} \mathrm{C}, 0.1 \mathrm{mbar}\right)$ for two days. After grinding and sieving algal biomass (L. digitata), the fraction below $250 \mu \mathrm{m}(30 \mathrm{~g})$ was dispersed into a $1 \%(\mathrm{w} / \mathrm{w}) \mathrm{Na}_{2} \mathrm{CO}_{3}$ solution $(800 \mathrm{~mL})$. The suspension was mixed for $24 \mathrm{~h}$ at a temperature of $50{ }^{\circ} \mathrm{C}$ for processing the partial extraction of alginate from algal biomass. Then, the suspension was mixed with $5 \mathrm{~mL}$ of PEI $(50 \%, \mathrm{w} / \mathrm{w})$; the suspension was dropped into $2 \mathrm{~L}$ of $\mathrm{CaCl}_{2}$ solution $(1 \%, \mathrm{w} / \mathrm{w})$, containing $5 \mathrm{~mL}$ of GA $(50 \mathrm{w} / \mathrm{w})$. The ionotropic gelation of alginate extracted from algal biomass operates through the interaction of carboxylate groups with calcium ions. The interaction of protonated amine groups of PEI with the carboxylate groups and crosslinking of amine groups from PEI moieties with carbonyl groups from GA also contribute to stabilize the beads (multiple interpenetrating network: alginate/PEI and alginate/Ca (II)).

\subsubsection{Epichlorohydrin-Activation of $A_{L} P E I$ Beads $\left(C l-A_{L} P E I\right)$}

Five grams of $A_{L}$ PEI beads were dropped into $100 \mathrm{~mL}$ ethanol/water solution (1:1, $v / v)$. Three grams of poly(ethyleneglycol) diglycidyl ether (PEGDE, for improving the strength of the beads and enhancing their stability) were added to the mixture under stirring for $5 \mathrm{~h}$ at $80^{\circ} \mathrm{C}$ (reactor equipped with a condenser).

Epichlorohydrin is a mediator frequently used in the grafting of functional groups onto polymer and biopolymer supports [50]. The beads were then transferred to a reactor containing $200 \mathrm{~mL}$ ethanol/water solution $(1: 1, v / v)$, in which a volume of $45 \mathrm{~mL}$ of epichlorohydrin was dropped wisely under gentle stirring. The suspension was refluxed for $3 \mathrm{~h}$ at $80-85^{\circ} \mathrm{C}$. The beads were filtered, washed with ethanol, and dried under vacuum to produce activated beads (spacer $\mathrm{Cl}$-bearing arms).

\subsubsection{Phosphorylation of Activated Beads $\left(\mathrm{P}^{*}\right.$ - $\left.\mathrm{A}_{\mathrm{L}} \mathrm{PEI}\right)$}

The activated beads $\left(\mathrm{Cl}-\mathrm{A}_{\mathrm{L}} \mathrm{PEI}\right)$ were dropped into $100 \mathrm{~mL}$ of triethyl phosphite. The reaction mixture was heated at $130^{\circ} \mathrm{C}$ for $24 \mathrm{~h}$ to produce phosphorylated $\mathrm{A}_{\mathrm{L}}$ PEI beads $\left(\mathrm{P}^{*}-\mathrm{A}_{\mathrm{L}} \mathrm{PEI}\right)$. The beads were filtered and washed several times with hot water and ethanol then dried under vacuum overnight.

\subsubsection{De-Esterification of $\mathrm{P}^{*}$ - $\mathrm{A}_{\mathrm{L}} \mathrm{PEI}$ Beads $\left(\mathrm{POH}-\mathrm{A}_{\mathrm{L}} \mathrm{PEI}\right)$}

The phosphorylated beads $\left(\mathrm{P}^{*}-\mathrm{A}_{\mathrm{L}} \mathrm{PEI}\right)$ were soaked into $75 \mathrm{~mL}$ of dichloromethane under stirring for $24 \mathrm{~h}$ at room temperature. Trimethyl silyl bromide (10 g) was added to the suspension under nitrogen and stirring at $30-35^{\circ} \mathrm{C}$ for $24 \mathrm{~h}$ to produce phosphonic acid-functionalized beads (POH- $\left.\mathrm{A}_{\mathrm{L}} \mathrm{PEI}\right)$. The beads were washed several times with hot water to remove the excess of unreacted bromide derivative, before being rinsed with acetone and dried in vacuum overnight.

Scheme 1 summarizes the different steps of the synthesis procedure. 

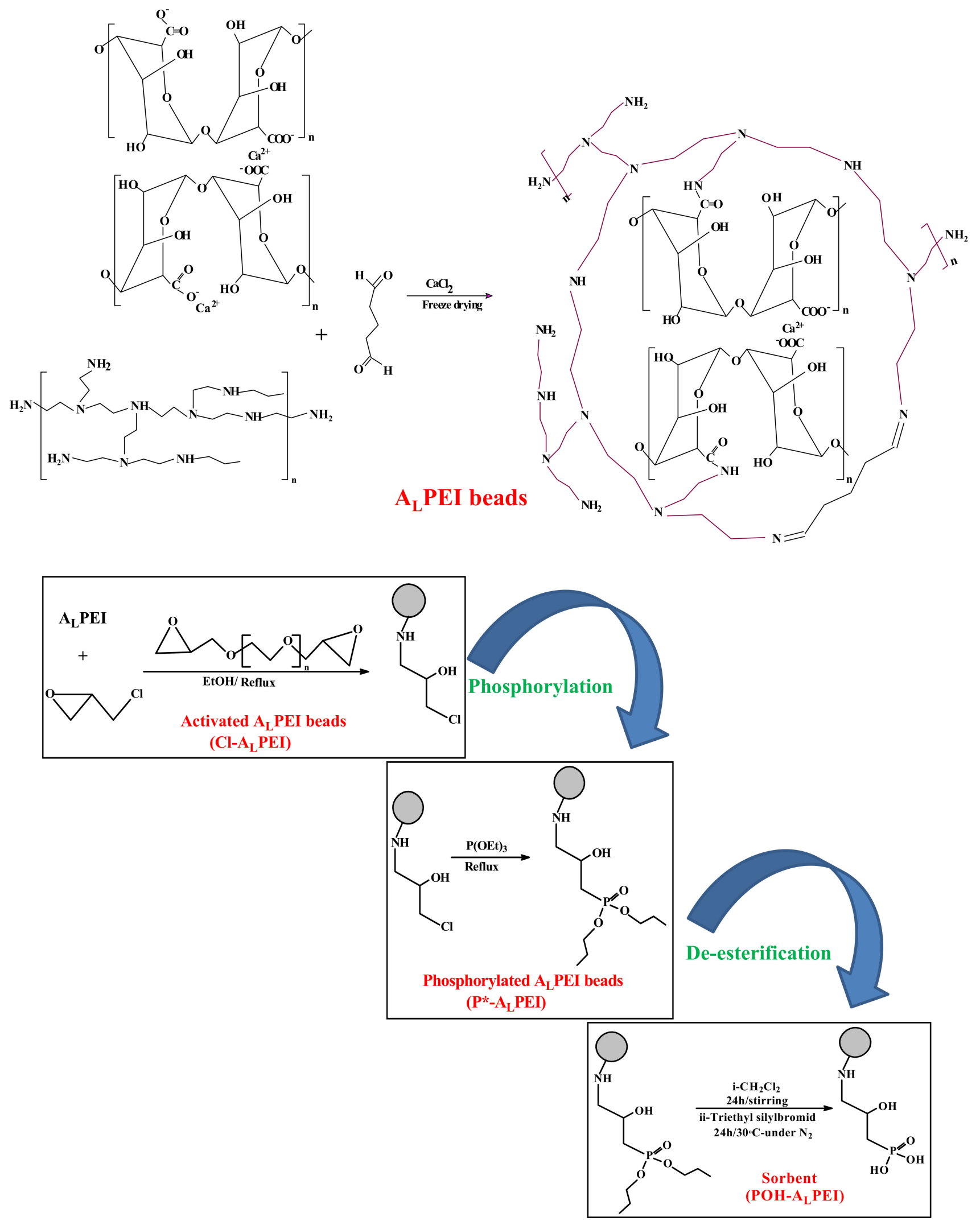

Scheme 1. Procedure for the synthesis of POH-A $\mathrm{L}$ PEI beads. 


\subsection{Characterization of Materials}

An ESCALAB 250XI+ instrument (Thermo Fischer Scientific, Inc., Waltham, MA, USA) was operated for collecting XPS spectra of the different materials (synthesis procedure, before and after metal sorption). The excitation source was monochromatic $\mathrm{Al} \mathrm{K}_{\alpha} \mathrm{X}$-ray radiation $(1486.6 \mathrm{eV})$ applied on a $500 \mu \mathrm{m}$ spot size. The pressure of the analytical chamber was less than $10^{-8}$ mbar. The analyzer used a $20 \mathrm{eV}$ pass energy for the acquisition of high-resolution core level spectra (50 eV for full spectrum analysis). The BE calibration was performed using $\mathrm{C} 1 \mathrm{~s}$ at $284.8 \mathrm{eV}$ for $\mathrm{C}_{\mathrm{adv}}, \mathrm{C}-\mathrm{C}$ - and $\mathrm{C}=\mathrm{C}$. The energy resolution on $\mathrm{Ag} 3 d_{5 / 2}$ was $0.45 \mathrm{eV}$ and $0.82 \mathrm{eV}$ for $\mathrm{C} 1 \mathrm{~s}$. FTIR spectra were acquired on dried samples (dispersed into KBr discs) using an IRTracer-100 (Shimadzu, Tokyo, Japan).

The morphology observation and the semi-quantitative surface analyses were obtained on a Phenom ProX scanning electron microscope (SEM, Thermo Fisher Scientific, Eindhoven, Netherlands) coupled with EDX facilities. The textural properties of the sorbents have been qualified using the BJH method and a Micromeritics TrisStar II (Norcross, GA, USA). The pre-treatment of the samples consisted of their degassing at $100{ }^{\circ} \mathrm{C}$ for $12 \mathrm{~h}$. A Netzsch STA 449 F3 Jupiter thermogravimeter was used for TGA analysis, with a temperature ramp of $10^{\circ} \mathrm{C} / \mathrm{min}$ (under oxygen or air atmosphere) (NETZSCH-Gerätebau $\mathrm{GmbH}$, Selb, Germany). The elemental composition of the sorbents was obtained on a Vario EL cube element analyzer (Elementar Analysensysteme $\mathrm{GmbH}$, Langenselbold, Germany). The $\mathrm{pH}_{\mathrm{PZC}}$ was determined using the $\mathrm{pH}$-drift method [51].

\subsection{Metal Sorption}

The loading of the sorbent with metal ions ( $\mathrm{La}(\mathrm{III})$ and $\mathrm{Tb}(\mathrm{III})$ ) was operated in a batch system by contact of the beads $(\mathrm{m}, \mathrm{g})$ with a volume $(\mathrm{V}, \mathrm{L})$ of solution containing $50 \mathrm{mg}$ metal L ${ }^{-1}$ (i.e., $\mathrm{C}_{0}$ : $0.375 \mathrm{mmol} \mathrm{La} \mathrm{L}^{-1}$ and $0.314 \mathrm{mmol} \mathrm{Tb} \mathrm{L}^{-1}$ ) at $\mathrm{pH}_{0}$ : 4 , room temperature for $24 \mathrm{~h}$. Final $\mathrm{pH}$ was recorded: $4.40-4.45$ for $\mathrm{La}$ (III) and $4.3-4.4$ for $\mathrm{Tb}$ (III). The investigation of the effect of the $\mathrm{pH}$ was carried out using the same procedure, except that the initial $\mathrm{pH}$ was varied in the range $\mathrm{pH}_{0}: 1-5$; the sorbent dose, $\mathrm{SD}\left(\mathrm{g} \mathrm{L}^{-1}, \mathrm{SD}=\mathrm{m} / \mathrm{V}\right)$. The final $\mathrm{pH}$ was monitored, and the residual concentration $\left(\mathrm{C}_{\mathrm{eq}}, \mathrm{mmol} \mathrm{L}^{-1}\right)$ was determined using an ICP-AES spectrometer (inductively coupled plasma atomic emission spectrometer, ICPS-7510 Shimadzu, Tokyo, Japan). The amount of metal bound to the sorbent ( $\mathrm{q}_{\mathrm{eq}}$, mmol g $\left.{ }^{-1}\right)$ was deduced from the mass balance equation: $\mathrm{q}_{\mathrm{eq}}=\left(\mathrm{C}_{0}-\mathrm{C}_{\mathrm{eq}}\right) \times \mathrm{V} / \mathrm{m}$. The distribution ratio $\left(\mathrm{D}, \mathrm{L} \mathrm{g}^{-1}\right)$ is calculated by $\mathrm{D}=\mathrm{q}_{\mathrm{eq}} / \mathrm{C}_{\mathrm{eq}}$. The FTIR spectra of materials exposed to five successive cycles of sorption/desorption for evaluating the stability of the sorbent. The eluent was an acidic calcium chloride solution (i.e., $0.2 \mathrm{M} \mathrm{HCl} / 0.5 \mathrm{M}$ $\mathrm{CaCl}_{2}$ ). In the investigation of sorbent recycling, a rinsing (with demineralized water) was systematically performed between each step.

\section{Results and Discussion}

\subsection{Physical Characterization of Sorbents}

\subsubsection{Morphology and Textural Characterization}

Figure 1 shows that the functionalized sorbent $\left(\mathrm{POH}-\mathrm{A}_{\mathrm{L}} \mathrm{PEI}\right.$ beads) is characterized by a roughly spherical shape; although some deformations occurred (probably associated to the drying steps of the hydrogels). The color of the beads has become lighter after metal sorption.

Table S1 in Supplementary Materials shows optical micrographs of the materials: the sorbents are roughly spherical, and the average bead size progressively decreases with the chemical modification of $A_{L}$ PEI (from $2.7 \mathrm{~mm}$ to $2.07 \mathrm{~mm}$ ). The surface is smoothed but uneven. This is confirmed by the SEM micrographs of the surface of the beads at the different stages of the synthesis (Table S2). On POH-A $A_{L}$ PEI beads, micro-cracks and folds appear on the surface of the sorbent. The SEM microphotographs of the crosscut section show the highly macroporous internal structure (laminated structure characterized by sheets and scaffolds; 50-200 $\mu \mathrm{m}$ size cell opening), especially for functionalized materials. Table S3 shows the semi-quantitative EDX analyses of surface and crosscut sections. The activation 
of the raw material $\left(\mathrm{Cl}-\mathrm{A}_{\mathrm{L}} \mathrm{PEI}\right)$ is confirmed by the appearance of $\mathrm{Cl}(4.1-4.7 \%$, weight fraction), the disappearance of $\mathrm{Cl}$ after phosphorylation $\left(\mathrm{P}^{*}-\mathrm{A}_{\mathrm{L}} \mathrm{PEI}\right)$ and de-esterification $\left(\mathrm{POH}-\mathrm{A}_{\mathrm{L}} \mathrm{PEI}\right)$ confirms the synthesis mechanism. The semi-quantitative analysis is roughly the same for surface and crosscut sections. After metal sorption, as expected, $\mathrm{La}$ and $\mathrm{Tb}$ appear (at levels close to 2.6-3.1\%, weight fraction) (see below); the weight fraction of $S$ increases from $0.2-0.3 \%$ (sorbent) to $1.7-2 \%$ after metal binding. This is consistent with the observations from the FTIR and XPS analyses.
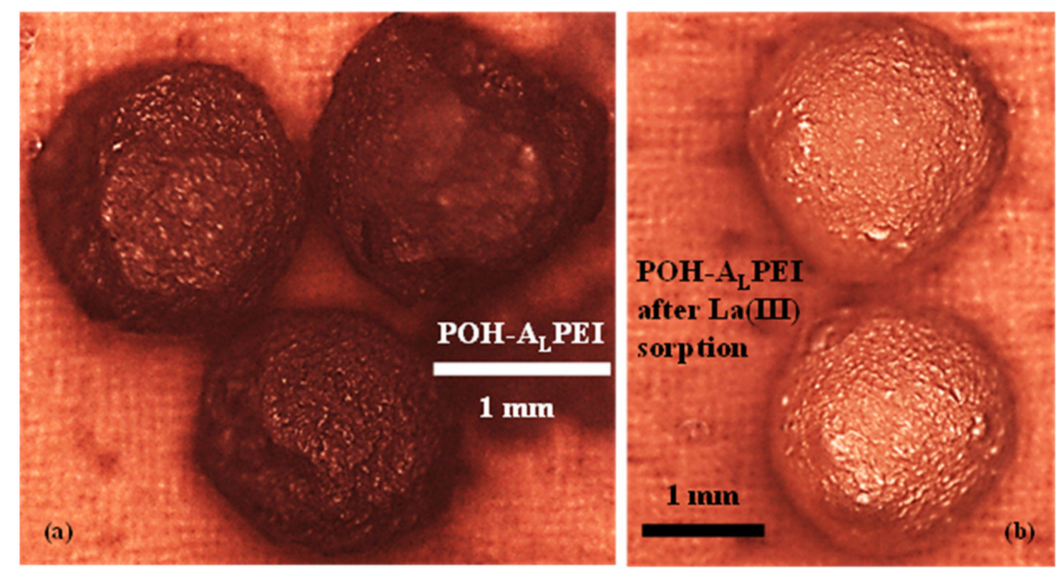

Figure 1. Photograph of sorbent particles—-before (a) and after La (III) sorption (b).

SEM pictures show that the materials can be considered heterogeneous with a tight external skin and a highly macro-porous internal compartment. The "compact" thin external layers proceeds from the ionotropic gelation of the beads while the macroporous cavities are associated with the freeze-drying procedure of the hydrogel network. The functionalization tends to block and/or coat the residual micro-porosity initially present in raw beads $\left(\mathrm{A}_{\mathrm{L}} \mathrm{PEI}\right)$.

\subsubsection{Thermogravimetric Analysis}

Figure $\mathrm{S} 1$ compares the profiles of thermal degradation (TGA and DrTG) for $A_{L}$ PEI and $\mathrm{POH}-\mathrm{A}_{\mathrm{L}} \mathrm{PEI}$ beads (and intermediary synthesis products). The TGA profile of $\mathrm{A}_{\mathrm{L}} \mathrm{PEI}$ is marked by four degradation steps, corresponding to:

- Water release (below $198^{\circ} \mathrm{C}$ ).

- Degradation of carbohydrate ring, polyethylenimine depolymerization (in the range $198-481^{\circ} \mathrm{C}$, maximum DrTG at $319.1^{\circ} \mathrm{C}$ ).

- Degradation of carbon-based backbone leading to char formation (in the range $184-639^{\circ} \mathrm{C}, \mathrm{DrTG}_{\max }$ at $500.2{ }^{\circ} \mathrm{C}$ ).

- And thermal degradation of the char $\left(\operatorname{DrTG}_{\max }\right.$ at $\left.500.2^{\circ} \mathrm{C}\right)$. Total weight loss reaches $82.9 \%$ at $909{ }^{\circ} \mathrm{C}$.

The chemically modified materials are characterized by smoother TGA profiles, where only 3 steps are identified; however, the DrTG profiles show an increased number of transitions (see Table associated with Figure S1), probably associated to the greater diversity of functional groups present on the materials. It is noteworthy that the thermal stability of the $\mathrm{Cl}-\mathrm{A}_{\mathrm{L}}$ PEI and $\mathrm{P}^{*}-\mathrm{A}_{\mathrm{L}}$ PEI materials is increased compared with the raw material: (a) the weight loss does not exceed 76.7 and $78.9 \%$, respectively, and (b) the weight loss curves are shifted toward higher temperatures $\left(\sim 500^{\circ} \mathrm{C}, \sim 549^{\circ} \mathrm{C}\right.$ and $\sim 600^{\circ} \mathrm{C}$ for $\mathrm{A}_{\mathrm{L}} \mathrm{PEI}$, $\mathrm{Cl}-\mathrm{A}_{\mathrm{L}} \mathrm{PEI}$ and $\mathrm{P}^{*}-\mathrm{A}_{\mathrm{L}} \mathrm{PEI}$, respectively). The incorporation of phosphorus compounds is well-known for improving the fire-properties of materials [52]. On the opposite hand, after de-esterification, the thermal degradation profile roughly turns back to the profile of $\mathrm{A}_{\mathrm{L}}$ PEI below $400{ }^{\circ} \mathrm{C}$, while the degradation is enhanced at higher temperatures: the total weight loss reaches $96.2 \%$ at $909{ }^{\circ} \mathrm{C}$. This diversity of degradation profiles confirms the 
substantial chemical modifications of the functionalized polymers in the different stages of the synthesis.

\subsubsection{Elemental Analysis and $\mathrm{pH}_{\mathrm{PZC}}$}

Another proof of the chemical modifications of the $\mathrm{A}_{\mathrm{L}} \mathrm{PEI}$ beads is provided by the comparison of the elemental compositions, which is summarized in Table S4. The progressive increase of the $C$ fraction with chemical modification is consistent with the grafting of new organic functions on the composite backbone, while de-esterification slightly decreases the $\mathrm{C}$ content (cleavage of ethyl groups). The $\mathrm{N}$ content decreases with the sorbent functionalization (from 3.48 to $2.78 \mathrm{mmol} \mathrm{N} \mathrm{g}^{-1}$ ): the grafting of supplementary organic functions logically reduces the relative amount of nitrogen. The variation in the $\mathrm{O}$ content follows a reciprocal tend: the $\mathrm{O}$ content progressively increases in the different stages of the synthesis, from 21.80 to $27.03 \mathrm{mmol} \mathrm{O} \mathrm{g}^{-1}$. This is consistent with the reagents used for activation $\left(\mathrm{Cl}-\mathrm{A}_{\mathrm{L}} \mathrm{PEI}\right)$ and for phosphorylation ( $3 \mathrm{O}$ per activated amine group). Efficient phosphorylation is demonstrated by quantification of $\mathrm{P}$ (reaching up to $2.1 \mathrm{mmol} \mathrm{P} \mathrm{g}^{-1}$ ). This phosphorylation on activated amine groups is highly efficient: the $\mathrm{N}$ content in $\mathrm{Cl}-\mathrm{A}_{\mathrm{L}} \mathrm{PEI}$ is close to $3 \mathrm{mmol} \mathrm{g}^{-1}$, to be compared with the final P content in the sorbent. This means that the grafting is close to $70 \%$; this is remarkable taking into account that (primary, secondary and tertiary, P-S-T) amine groups may have different reactivity and accessibility in branched PEI.

Figure $\mathrm{S} 2$ compares the $\mathrm{pH}_{\mathrm{PZC}}$ of raw and functionalized beads. Chemical modification of $\mathrm{A}_{\mathrm{L}} \mathrm{PEI}$ significantly shifts the $\mathrm{pH}_{\mathrm{PZC}}$ of the material (from 4.29 to 6.82). The raw material bears amine groups (P-S-T; $\mathrm{PK}_{\mathrm{a}}: 4.5,6.7$ and 11.6, respectively) from PEI and carboxylic groups (mannuronic and guluronic acid; $\mathrm{pK}_{\mathrm{a}}: 3.38$ and 3.65 , respectively) from alginate. By grafting phosphonic groups the acid-base properties are substantially modified, and the sorbent is protonated in acidic solutions (including close to a neutral $\mathrm{pH})$. Kolodynska et al. [53] compared the sorption properties of a series of chelating resins for lanthanum sorption and reported $\mathrm{pH}_{\mathrm{PZC}}$ values of aminophosphonic-based resins in the range 8.13-9.93. Glowinska and Trochimczuk [54] reminded that the two $\mathrm{pK}_{\mathrm{a}}$ of phosphonic groups are close to 1.3 and 6.70. These properties are critical for defining the affinity of sorbents for target metal ions (attraction/repulsion) and sorption mechanisms (chelation vs. ion-exchange/electrostatic attraction).

\subsection{Synthesis of POH- $A_{L}$ PEI Beads-Chemical Characterization}

The different materials elaborated in the suggested route for sorbent synthesis (as reported in Scheme 1) are analyzed by FTIR and XPS spectroscopies to identify the reactive groups and how they are affected by the successive reactions.

\subsubsection{FTIR Spectroscopy}

Figure 2 compares the FTIR spectra of the raw material $\left(\mathrm{A}_{\mathrm{L}} \mathrm{PEI}\right)$ and the sorbent $(\mathrm{POH}-$ $\mathrm{A}_{\mathrm{L}} \mathrm{PEI}$ ), including intermediary products. Focused windows (in specific wavenumber ranges) are reported in Figure S3 (see Supplementary Materials). Brown algal biomass (L. digitata) contains an important alginate: based on the literature, this fraction may reach up to 50\% [55], although this composition may vary with location and season [56,57]. This fraction of alginate is partially extracted by sodium carbonate with heating and may be available for further reaction with other constituents of the sorbent. In addition, the biomass contains other carbohydrates (such as fucoidan) or sugars (glucose and mannitol) and proteins.

The incorporation and reaction of protonated amine groups of PEI with carboxylic acid of alginate contributes to the structuration of the hydrogel, which is reinforced by gelation of the alginate with calcium chloride. This means that a wide variety of functional groups may be present on the support $\left(\mathrm{A}_{\mathrm{L}} \mathrm{PEI}\right)$, e.g., mainly, carboxylic groups (alginate, proteins), sulfonic groups (from fucoidans), amine groups (from PEI, proteins; primary, secondary and tertiary amines) and hydroxyl groups. This may explain the broad bands observed in 
the FTIR spectra for $\mathrm{A}_{\mathrm{L}} \mathrm{PEI}$ and its derivatives: the superposition of spectral domains makes the interpretation and identification of peaks that may overlap and convolve complex. Different important spectral regions can be identified in relation with the chemical groups present in the materials [58]. Table S5 reports the assignments of the main peaks.

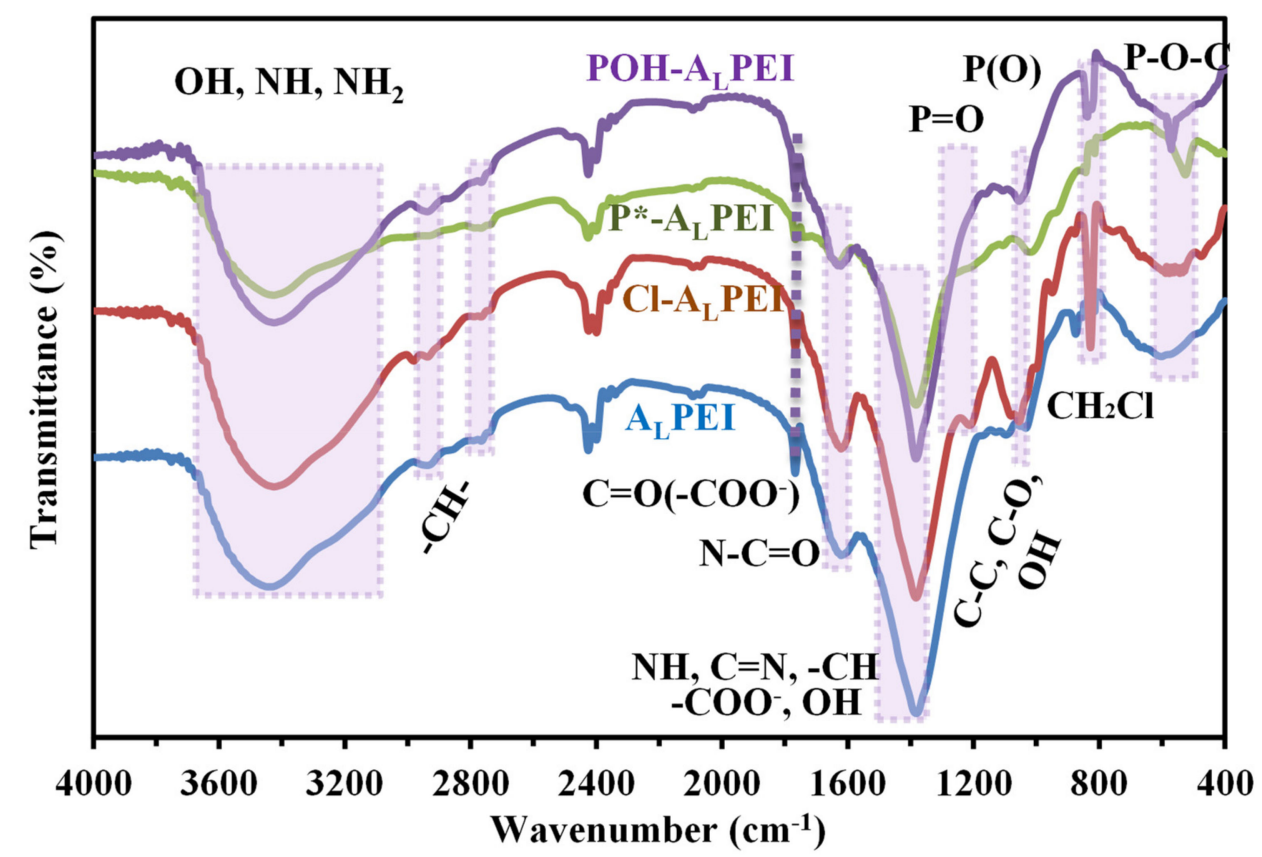

Figure 2. FTIR spectra of $A_{L} P E I$, intermediary products (epichlorohydrine-activated $A_{L} P E I, C l-$ $\mathrm{A}_{\mathrm{L}} \mathrm{PEI}$ and phosphorylated $\mathrm{A}_{\mathrm{L}} \mathrm{PEI}$ beads, $\mathrm{P}^{*}$ - $\mathrm{A}_{\mathrm{L}} \mathrm{PEI}$ ) and sorbent (de-esterified phosphorylated beads, $\left.\mathrm{POH}-\mathrm{A}_{\mathrm{L}} \mathrm{PEI}\right)$.

- $\quad$ Region $3800-2200 \mathrm{~cm}^{-1}$

In this wavenumber range, a poorly resolved broad band can be identified by a peak at $\sim 3450 \mathrm{~cm}^{-1}$ and a shoulder at $\sim 3250 \mathrm{~cm}^{-1}$, corresponding to the convolution of different stretching vibrations of $-\mathrm{OH}$ and $-\mathrm{NH}$. In addition, stretching vibrations of $-\mathrm{CH}$ bonds are appearing in the region $2980-2850 \mathrm{~cm}^{-1}$ confirming the expected presence of linear aliphatic chains. It is noteworthy that additional weak peaks can be observed at lower wavenumber (i.e., around 2762 and $2739 \mathrm{~cm}^{-1}$ ), which could be assigned to methylamino groups. Two peaks are identified at $\sim 2430$ and $\sim 2400 \mathrm{~cm}^{-1}$, which may be attributed to carbonate and/or $\mathrm{CO}_{2}$ absorption. Actually, the four materials show very comparable FTIR patterns. Chemical changes do not appear clearly in this wavenumber range, because of the superimposition of different bands present in the different reagents.

- Region $1800-1200 \mathrm{~cm}^{-1}$

In this region, the sorbents also show very similar patterns. A first well-resolved band is observed at $1767 \mathrm{~cm}^{-1}$, which is usually assigned to $\mathrm{C}=\mathrm{O}$ stretching vibration in carboxylic groups. Its relative intensity decreases after reaction with epichlorohydrin and PEGDE (Cl- $\left.\mathrm{A}_{\mathrm{L}} \mathrm{PEI}\right)$. The intensity continues to decrease with phosphorylation $\left(\mathrm{P}^{*}-\mathrm{A}_{\mathrm{L}} \mathrm{PEI}\right)$, which is accompanied by the appearance of a weak peak at $1726 \mathrm{~cm}^{-1}$ (attributed to $\mathrm{C}=\mathrm{O}$ stretching in ester groups). This additional weak peak disappears after de-esterification $\left(\mathrm{POH}-\mathrm{A}_{\mathrm{L}} \mathrm{PEI}\right)$, due to the increase in the contribution of the $\mathrm{OH}$ stretching vibration. The second broad peak is observed in the wavenumber range $1632-1622 \mathrm{~cm}^{-1}$; this large band may be assigned to $\mathrm{C}=\mathrm{O}$ asymmetric stretching in $\left(\mathrm{COO}^{-}\right),(-\mathrm{N}-\mathrm{H})$ bending vibration (for primary and secondary amines) and/or open-chain imino groups $(-\mathrm{C}=\mathrm{N}-)$. The strongest peak is identified for the four materials at $1382 \pm 1 \mathrm{~cm}^{-1}$. This peak is broad as shown by the full width at half maximum (FWHM) that exceeds $100 \mathrm{~cm}^{-1}$ and corresponds to the superposition of different signals corresponding to contributions of carboxylate 
(symmetric stretching, 1420-1300 $\mathrm{cm}^{-1}$ ), -OH bending (for carboxylic acid and aldehyde), $-\mathrm{C}-\mathrm{H}$ bending, $\mathrm{C}-\mathrm{N}$ stretching and $\mathrm{S}=\mathrm{O}$ stretching (for sulfonic groups of fucoidans). The activation of $A_{L}$ PEI is followed by the appearance of a new peak at $1213 \mathrm{~cm}^{-1}$. This peak is a tracer of chloromethylation of amine groups (associated with the action of PEGDE); Kuo et al. [59] investigated the epoxidation of bark with epichlorohydrin and reported the appearance of a specific epoxide band in this region. The peak disappears almost completely after phosphorylation. This is a confirmation of the efficiency of epichlorohydrin in promoting the quantitative phosphorylation of the support.

- Region 1200-500 $\mathrm{cm}^{-1}$

The spectrum of $A_{L}$ PEI shows weak peaks in the $1170-1050 \mathrm{~cm}^{-1}$ range that correspond to $\mathrm{C}-\mathrm{C}, \mathrm{C}-\mathrm{O}-\mathrm{C}$ and $\mathrm{C}-\mathrm{O}$ (in alcohols) stretching vibrations (associated with carbohydrate ring), and C-N stretching. After epichlorohydrin-activation (including PEGDE grafting), the spectrum of $\mathrm{Cl}-\mathrm{A}_{\mathrm{L}} \mathrm{PEI}$ shows a series of peaks at $1080 \mathrm{~cm}^{-1}$ (C-O and C-C stretching), $1055 \mathrm{~cm}^{-1}$ (C-N stretching), $1001 \mathrm{~cm}^{-1}$ (C-O-C stretching), $949 \mathrm{~cm}^{-1}$ (epoxide asymmetric stretching, [60]), and $827 \mathrm{~cm}^{-1}\left(\mathrm{CH}_{2}-\mathrm{Cl}\right.$ stretching). The relative intensities of these bands decrease after phosphorylation $\left(\mathrm{P}^{*}-\mathrm{A}_{\mathrm{L}} \mathrm{PEI}\right)$, while the sharp peak at $827 \mathrm{~cm}^{-1}$ disappears: the grafting operates quantitatively on the pending $\mathrm{CH}_{2}-\mathrm{Cl}$ groups.

Zenobi et al. reported the effect of $\mathrm{pH}$ on the FTIR spectra of different phosphonic acids in solution [61], and after sorption onto boehmite [62]: significant shifts are observed when varying $\mathrm{pH}$ and these changes are completed with additional peaks after adsorption (double impact of $\mathrm{pH}$ and interaction/chemical environment). The phosphorylation of $\mathrm{Cl}-\mathrm{A}_{\mathrm{L}} \mathrm{PEI}$ (i.e., $\mathrm{P}^{*}$ - $\mathrm{A}_{\mathrm{L}} \mathrm{PEI}$ ) is characterized by the appearance of a series of weak peaks at $1107 \mathrm{~cm}^{-1}$ (organic phosphates $\mathrm{P}=\mathrm{O}$ stretch), $1018 \mathrm{~cm}^{-1}, 942 \mathrm{~cm}^{-1}$ and $527 \mathrm{~cm}^{-1}$ (symmetric stretching of P-O-C), and 1050-990 $\mathrm{cm}^{-1}$ (P-O-C stretching) [61]. After deesterification (i.e., $\mathrm{POH}-\mathrm{A}_{\mathrm{L}} \mathrm{PEI}$ ), the intensity of shoulder at around $\sim 1180 \mathrm{~cm}^{-1}$ decreases (stretching of $\mathrm{P}=\mathrm{O}$ band, [63]); the bands at $1018 \mathrm{~cm}^{-1}$ and $527 \mathrm{~cm}^{-1}$ are shifted to 1055 and $571 \mathrm{~cm}^{-1}$, respectively. A doublet also appears at 837 and $831 \mathrm{~cm}^{-1}$ (probably associated with P-O-C deformation, $\sim 780 \mathrm{mn}^{-1}$ according to Illy et al. [63]).

The change in the environment of phosphorus in phosphonate functional groups significantly modified the FTIR spectrum in this region, as a confirmation of the deesterification reaction.

\subsubsection{XPS Spectroscopy}

The characterization of $A_{L}$ PEI functionalization is completed by XPS analysis of the different intermediary compounds. Figure 3 shows the survey spectra of the studied samples (where selected binding energy ranges are highlighted; completed by selected HRES signals, appearing in Figures S4-S8).

The chemical modifications are clearly shown when comparing the profiles of the signals and their deconvolutions. Figure 4 shows the substantial changes of the $\mathrm{C} 1 \mathrm{~s}$ core level spectra along the successive grafting steps. With the epichlorohydrin activation, the relative intensities of the deconvoluted signals weakly change (limited shifts).

The phosphorylation drastically increases the relative intensities of $\mathrm{C}-\mathrm{C}$ and $\mathrm{C}=\mathrm{C}$ against those of $\mathrm{C}-\mathrm{OH}, \mathrm{C}-\mathrm{O}-\mathrm{C}, \mathrm{C}=\mathrm{O}$ (amide), and carboxyl. The de-esterification step restores the $\mathrm{C} 1 \mathrm{~s}$ core level spectrum (similar to the epichlorohydrin-activated material (due to the change in the chemical environment of phosphoryl group). Some changes are also observed on $\mathrm{O} 1 s$ core level spectra (Figure 5); apart from the changes in intensity and weak shifts, the most relevant differences are observed for $P^{*}-A_{L} P E I$ and $\mathrm{POH}-\mathrm{A}_{\mathrm{L}} \mathrm{PEI}$ (phosphorylated materials) with the disappearance of $\mathrm{C}-\mathrm{O}$ (carboxylate) and $\mathrm{C}=\mathrm{O}$ (amide) contributions. For $\mathrm{N} 1 s$ core level (Figure 6), the modification of $\mathrm{A}_{\mathrm{L}} \mathrm{PEI}$ is followed by a reinforcement of the contribution of alkyl ammonium signal. In addition, the de-esterification leads to the appearance of a new signal, assigned to $\mathrm{N}$ (amide) at BE: $400.6 \mathrm{eV}$. The de-esterification of $\mathrm{P}^{*}$ - $\mathrm{A}_{\mathrm{L}} \mathrm{PEI}$, maintains the shape of the P $2 p$ core level spectrum; however, a shift towards lower BEs is observed (Figure 7). Table S6 shows the binding energies (BEs, eV), atomic fraction (\%) and possible assignments of the deconvo- 
luted peaks. The successive modifications of the raw beads lead to substantial changes in $\mathrm{C} 1 \mathrm{~s}, \mathrm{O} 1 \mathrm{~s}$ and $\mathrm{N} 1 \mathrm{~s}$ core level spectra with modifications in the relative contributions and appearance/disappearance of specific functional groups. For example, in the case of $C$ $1 s$, the activation of the support hardly changes the HRES XPS profile, with only a weak decrease in the relative contribution of amide group. It is possible to assign the signal at $286.5 \mathrm{eV}$ to different contributions, including to that of the $\mathrm{C}-\mathrm{Cl}$ covalent bond [64]. This $\mathrm{C}-\mathrm{Cl}$ bond is confirmed by the $\mathrm{Cl} 2 p_{3 / 2}$ contribution at $199.9 \mathrm{eV}$ for $\mathrm{Cl}-\mathrm{A}_{\mathrm{L}} \mathrm{PEI}$, in addition to the $\mathrm{C}-\mathrm{Cl}$ covalent bonding. In contrast, after phosphorylation, the profile completely changes with a significant reinforcement of the peak at $\sim 284.8 \mathrm{eV}$ ( $\mathrm{C}-\mathrm{C}$ and $\mathrm{C}=\mathrm{C}$ functional groups) and C-P of the phosphonic group [65].
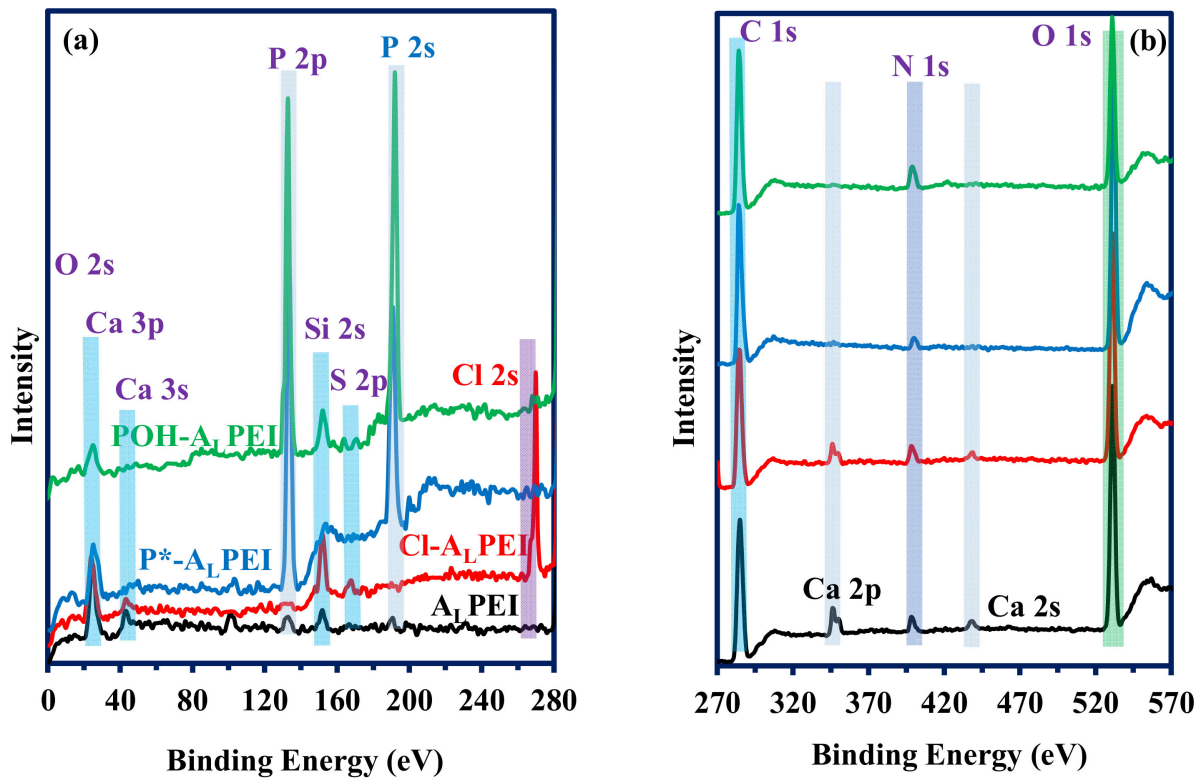

Figure 3. XPS survey spectra of $A_{L}$ PEI beads, intermediary products (epichlorohydrin-activated $\mathrm{A}_{\mathrm{L}}$ PEI, $\mathrm{Cl}-\mathrm{A}_{\mathrm{L}} \mathrm{PEI}$ and phosphorylated $\mathrm{A}_{\mathrm{L}} \mathrm{PEI}$ beads, $\mathrm{P}^{*}-\mathrm{A}_{\mathrm{L}} \mathrm{PEI}$ ) and sorbent (de-esterified phosphorylated beads, $\left.\mathrm{POH}-\mathrm{A}_{\mathrm{L}} \mathrm{PEI}\right)$-Focus on selected ranges of $\mathrm{BEs}((\mathbf{a}): 0.280 \mathrm{eV} ;(\mathbf{b}): 270-570 \mathrm{eV})$.
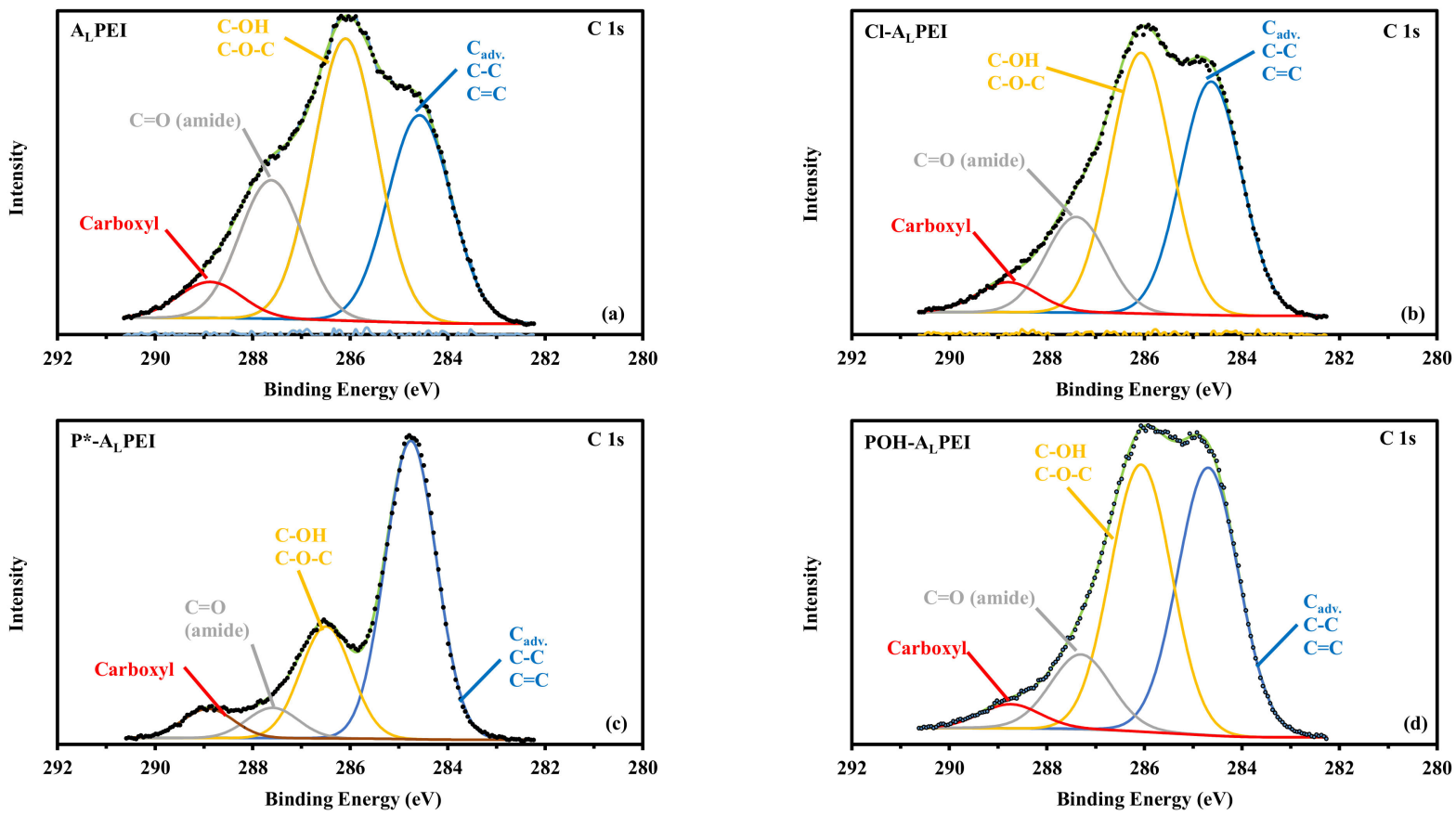

Figure 4. HRES XPS C 1 s core level spectra for $\mathrm{A}_{\mathrm{L}} \mathrm{PEI}(\mathbf{a}), \mathrm{Cl}-\mathrm{A}_{\mathrm{L}} \mathrm{PEI}(\mathbf{b}), \mathrm{P}^{*}-\mathrm{A}_{\mathrm{L}} \mathrm{PEI}(\mathbf{c})$ and POH-A $\mathrm{LEI}(\mathbf{d})$. 

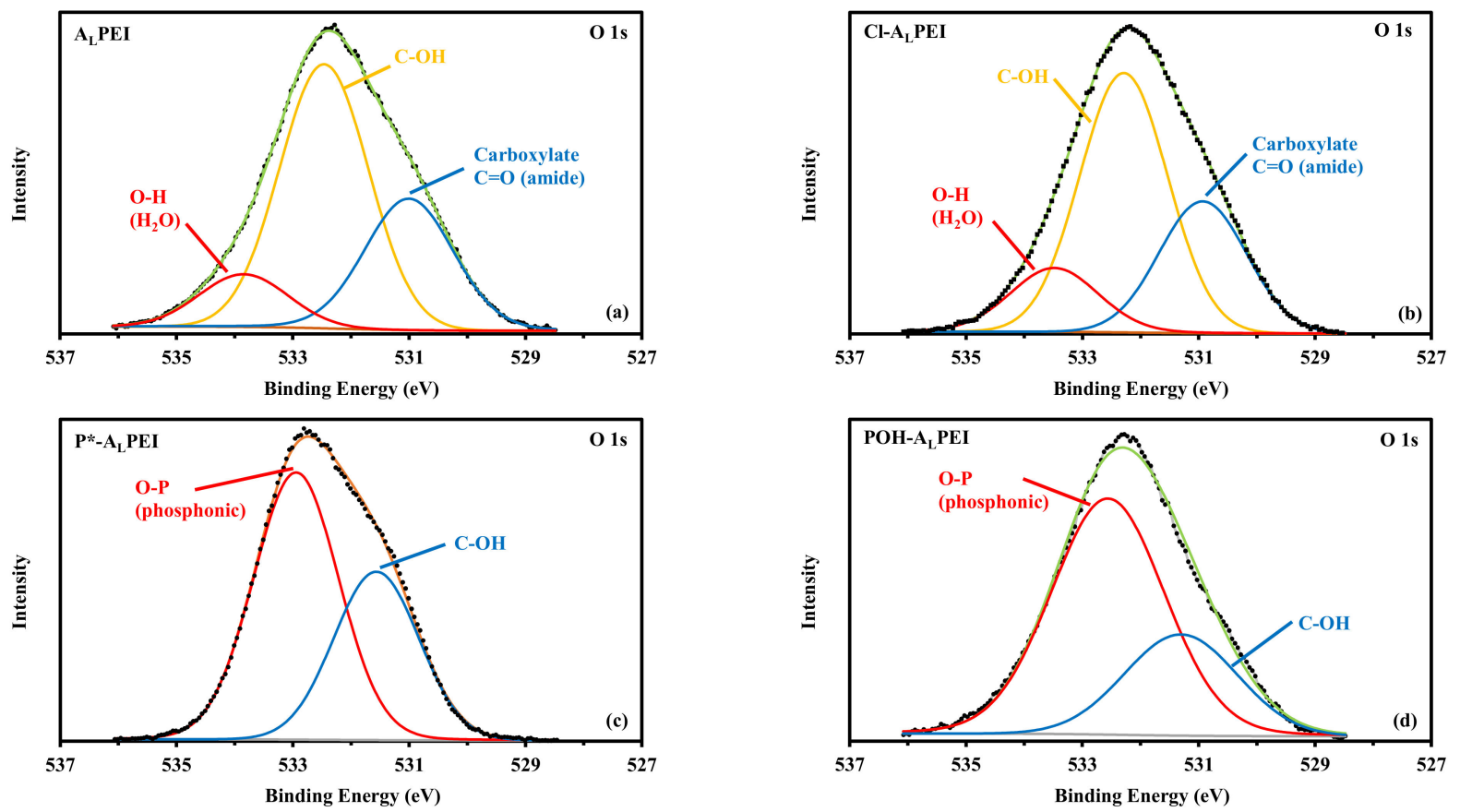

Figure 5. HRES XPS O 1 s core level spectra for $A_{L}$ PEI (a), Cl- $A_{L}$ PEI (b), $P^{*}-A_{L}$ PEI (c) and POH- $A_{L}$ PEI (d).
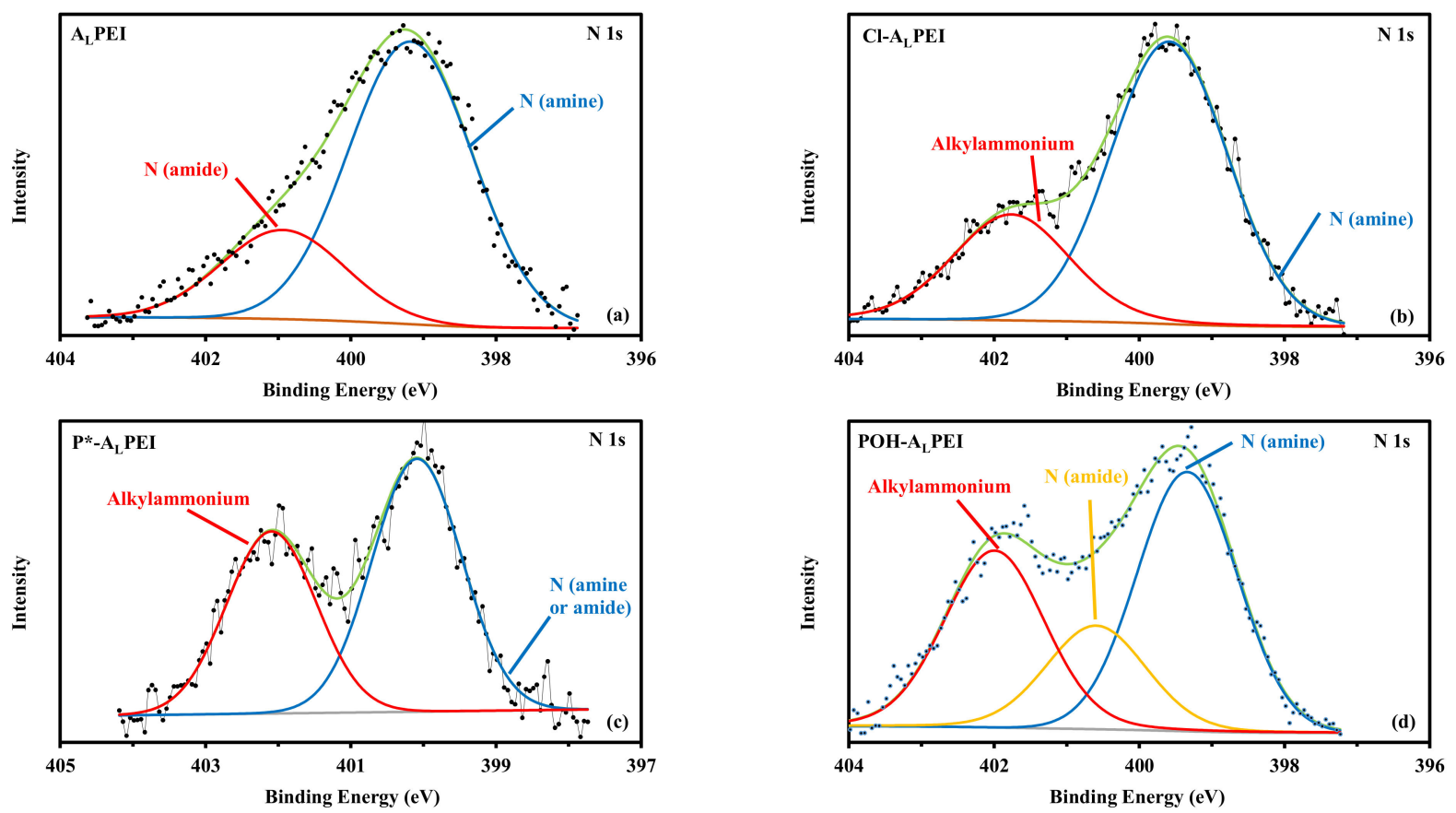

Figure 6. HRES XPS N 1 s core level spectra for $A_{L} P E I(a), C l-A_{L} P E I(b), P^{*}-A_{L} P E I(c)$ and POH- $A_{L} P E I(d)$. 

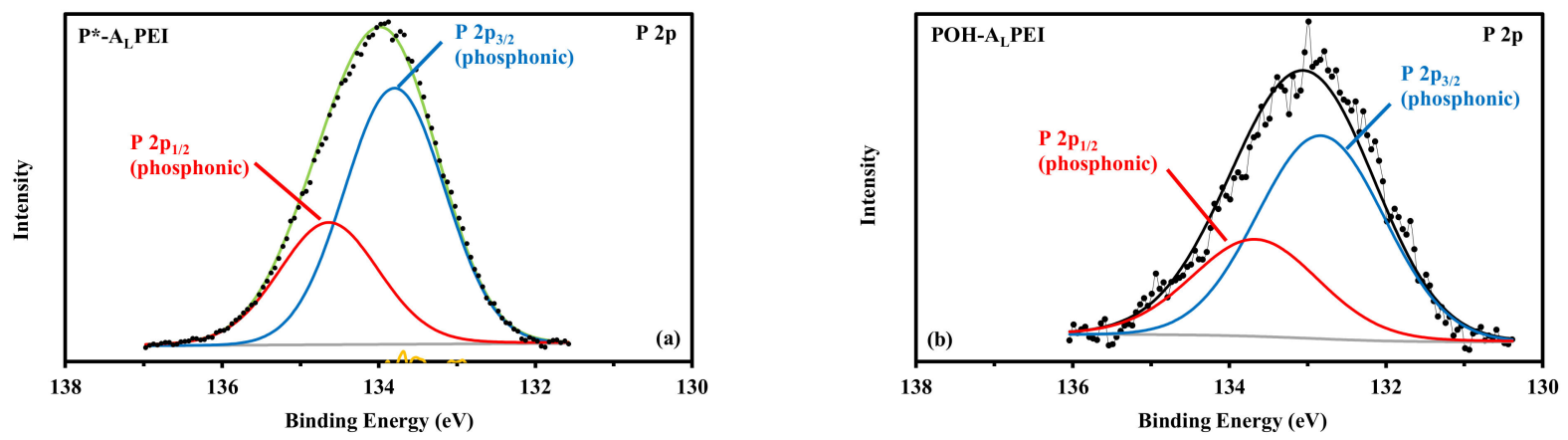

Figure 7. HRES XPS P $2 p$ core level spectra for $\mathrm{P}^{*}-\mathrm{A}_{\mathrm{L}} \mathrm{PEI}(\mathbf{a})$ and $\mathrm{POH}-\mathrm{A}_{\mathrm{L}} \mathrm{PEI}(\mathbf{b})$.

3.3. Characterization of the Interactions of POH- $A_{L} P E I$ with La(III) and Tb(III) Metal Ions

3.3.1. FTIR Spectroscopy

For $A_{L} P E I$, the most significant changes appearing with metal sorption are identified in the regions (Figure 8, Tables S7 and S8):

1. $\sim 1753 \mathrm{~cm}^{-1}$ — the $\mathrm{C}=\mathrm{O}$ stretching band disappears after $\mathrm{La}$ (III) and $\mathrm{Tb}$ (III) sorption;

2. And 1440-1370 $\mathrm{cm}^{-1}$ - the major peak is shifted from $1382 \mathrm{~cm}^{-1}$ to $\sim 1430 \mathrm{~cm}^{-1}$. Actually, the FTIR spectra show a broad band, which results from the convolution of different signals; after metal binding, relative contributions of carboxyl and amine groups are modified: these groups are involved in metal binding.
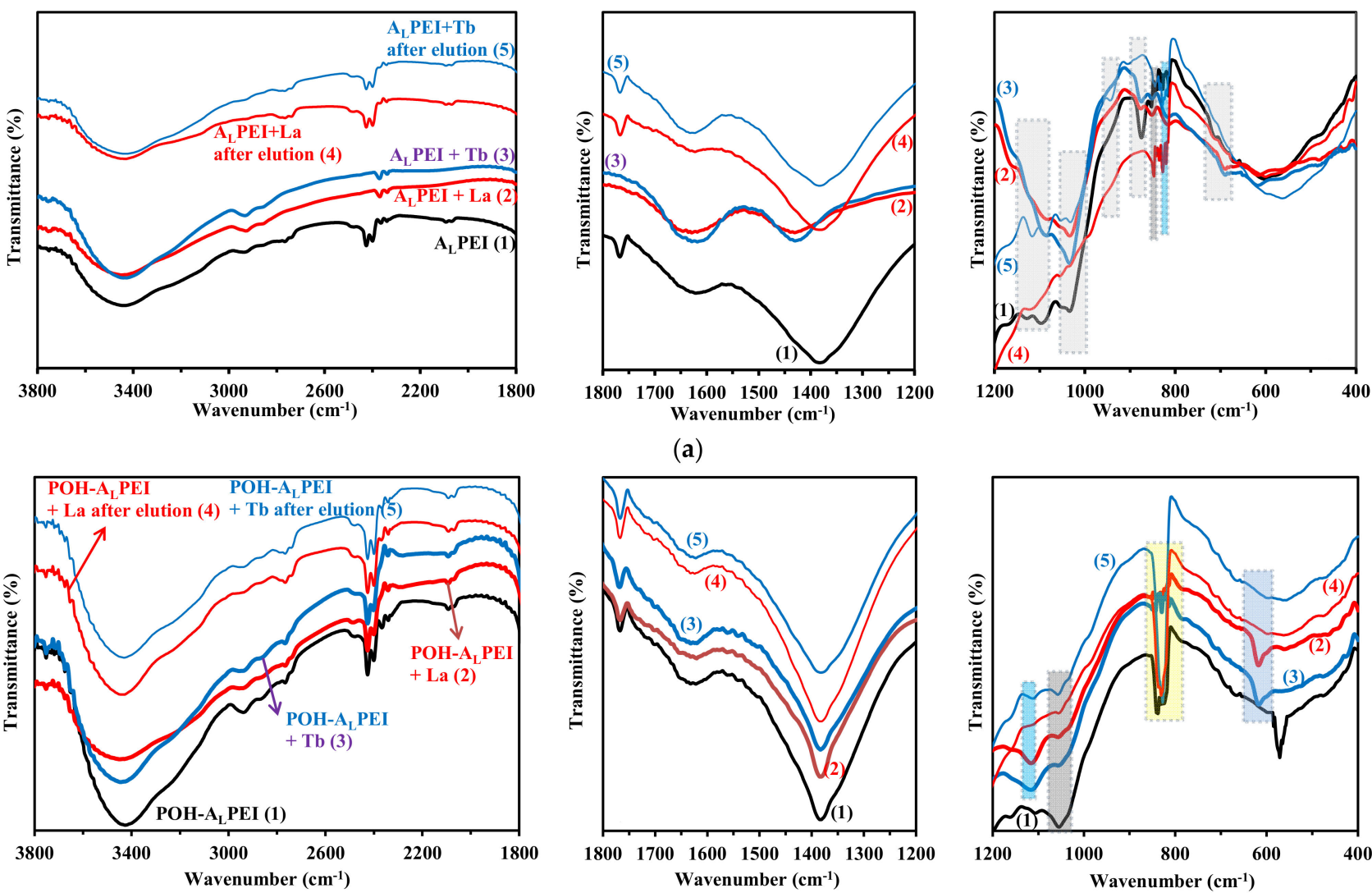

(b)

Figure 8. FTIR spectra of $\mathrm{A}_{\mathrm{L}} \mathrm{PEI}(\mathbf{a})$ and $\mathrm{POH}-\mathrm{A}_{\mathrm{L}} \mathrm{PEI}(\mathbf{b})$, before metal sorption and after metal desorption (focus on different wavenumber ranges).

It is noteworthy that after metal desorption the peaks are restored: the $1753 \mathrm{~cm}^{-1}$ peak reappears, while the $\sim 1430 \mathrm{~cm}^{-1}$ band is shifted back to $\sim 1382 \mathrm{~cm}^{-1}$. This means that 
the sorbent can be readily regenerated with limited degradation of the material (see below the confirmation of performance stability through recycling tests).

In the case of POH-A $A_{L} P E I$, the peaks relative to carboxyl and amine groups appear to be less affected by metal uptake $\left(\sim 1753 \mathrm{~cm}^{-1}\right.$ and $\left.\sim 1440-1370 \mathrm{~cm}^{-1}\right)$ : a slight enlargement of the broad band may be identified at $\sim 1350 \mathrm{~cm}^{-1}$. More significant variations appear around $1115 \mathrm{~cm}^{-1}$ (P-O stretching vibration), $1057 \mathrm{~cm}^{-1}$ (C-O and C-N stretching vibration), in the range $838-808 \mathrm{~cm}^{-1}$ (P-O-C stretching vibration), at $617 \mathrm{~cm}^{-1}$ (sulfate ion) and $571 \mathrm{~cm}^{-1}$ (P-O-C stretching vibration). The sorption of $\mathrm{La}$ (III) and $\mathrm{Tb}$ (III) is followed by the disappearance of the P-O-C vibration (at $838-808 \mathrm{~cm}^{-1}$ and $571 \mathrm{~cm}^{-1}$ ). After metal elution, the peak at $838-808 \mathrm{~cm}^{-1}$ reappears (contrary to the peak at $571 \mathrm{~cm}^{-1}$ : the sorption/desorption cycle durably affects the environment of this reactive group). The appearance of the peak at $1115 \mathrm{~cm}^{-1}$ (intensity increase) confirms that metal sorption reversibly affects the environment of phosphonic groups. The weakening of the peak at $1057 \mathrm{~cm}^{-1}$ shows that the amine and carboxyl groups may contribute to metal binding; however, the weak density of these reactive groups after functionalization of the support alters the visibility of this peak. The peak at $617 \mathrm{~cm}^{-1}$ (attributed to sulfate ion) indicates that the metals are probably bound as metal-sulfate species (or at least that sulfate anions are bound on the sorbents); the peaks disappear after metal desorption.

\subsubsection{XPS Spectroscopy}

XPS spectroscopy can be used not only for the characterization of the sorbent but also for the identification of binding mechanisms [66,67]. The sorption mechanisms can be also approached by the variations in the XPS spectra of the sorbents exposed to La (III) and $\mathrm{Tb}$ (III) solutions for selected signals (Figure 9, survey spectra, Figures 10 and 11 HRES XPS spectra, and Table S9).
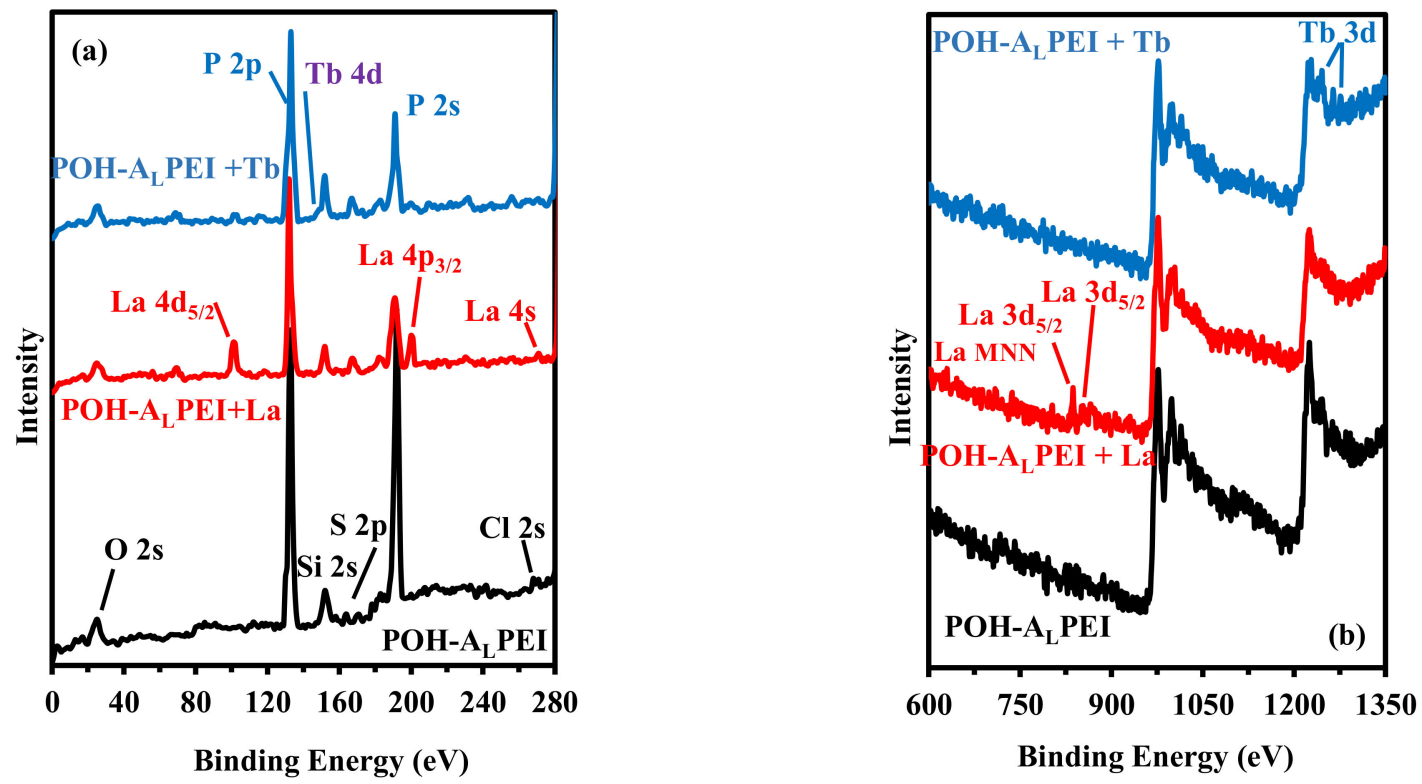

Figure 9. XPS survey spectra of $\mathrm{A}_{\mathrm{L}} \mathrm{PEI}$ beads (before and after $\mathrm{La}(\mathrm{III})$ and $\mathrm{Tb}(\mathrm{III})$ sorption (focus on selected ranges of $\mathrm{BEs}$ (a): 0-280 eV; (b) 600-1350 eV). 

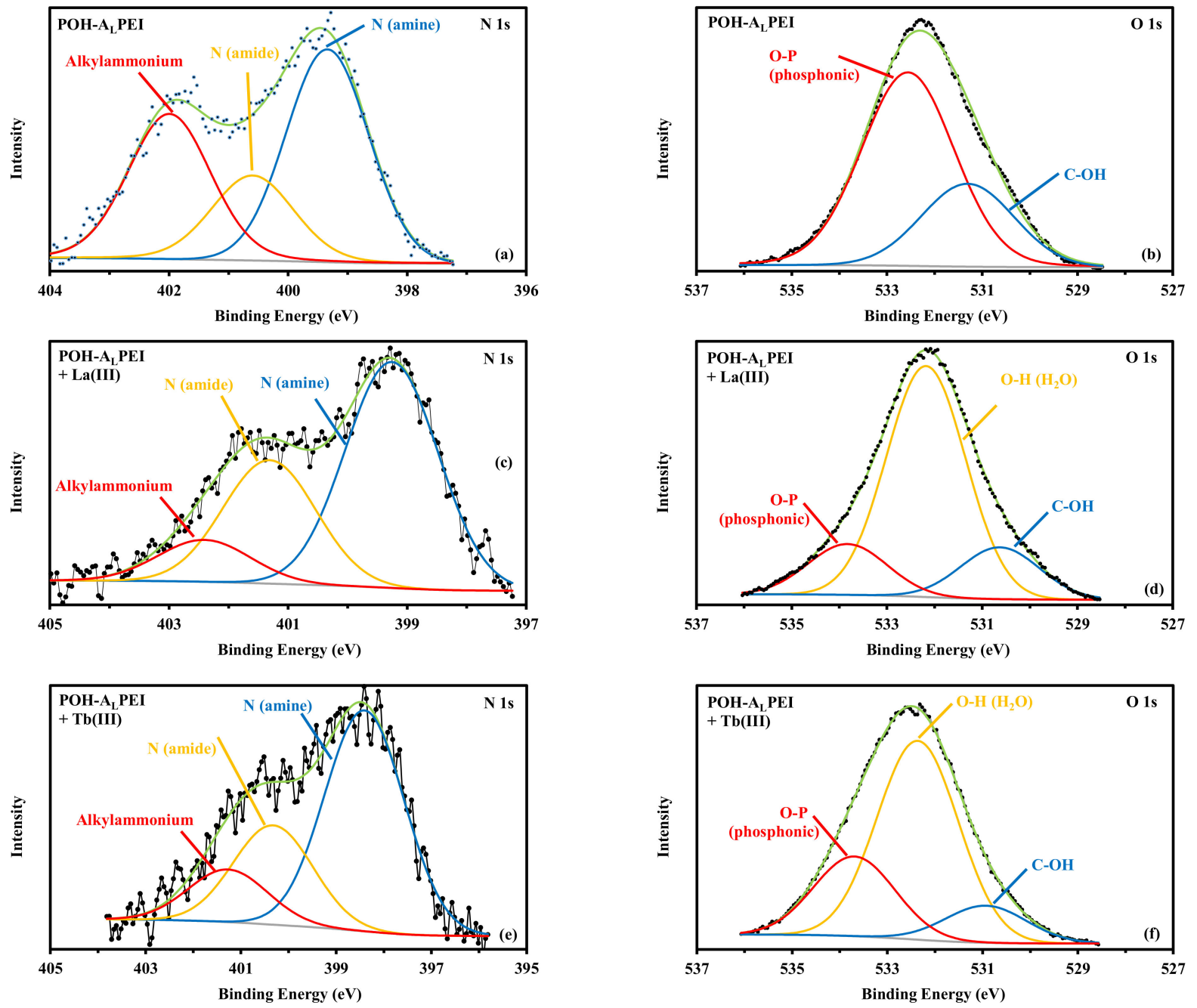

Figure 10. HRES XPS N 1s (a,c,e) and O 1s $(\mathbf{b}, \mathbf{d}, \mathbf{f})$ core level spectra for POH-A $\mathrm{A}_{\mathrm{L}}$ PEI before $(\mathbf{a}, \mathbf{b})$ and after metal sorption (La(III): (c,d); $\mathrm{Tb}(\mathrm{III}):(\mathbf{e}, \mathbf{f}))$.

The HRES spectra for selected elements are reported in Figures S9 and S10. The C 1s signal is poorly affected by metal binding in terms of BEs and AFs. The signal $\mathrm{O} 1 s$ shows more modifications: little shifts in the BEs $(-\triangle \mathrm{BEs}$ for both carboxylate $/ \mathrm{C}=\mathrm{O}$ (amide) groups and O-P phosphonic groups) and decrease in relevant AFs. The deconvolution of the global signal reveals after metal sorption the appearance of supplementary $\mathrm{O}-\mathrm{H}$ (from $\mathrm{H}_{2} \mathrm{O}$ ) on the sorbent: the metal ions may be sorbed under their hydrated form (solvated form). In addition, the appearance of $\mathrm{S} 2 p$ signal confirms the FTIR observations: appearance of sulfate by direct binding and/or binding of metal-sulfate species. The comparison of deconvoluted signals for $\mathrm{N} 1 s$ signal shows that metal binding is followed by a decrease of the relative contribution of alkyl ammonium signal (in favor of amine and amide signals): the environment of amine groups is probably affected by metal bonds, probably associated with charge neutralization of protonated amine groups with anionic metal species. The P $2 p$ signal is sifted toward higher binding energy values after $\mathrm{Tb}$ (III) sorption ( $\triangle$ BEs: $+0.4-0.5 \mathrm{eV}$ ) and even more for La (III) binding ( $\triangle$ BEs: $+1.5-1.6 \mathrm{eV})$. The sorption of these REEs involves a contribution of phosphonic groups, consistently with the conclusions raised for FTIR study. The presence of lanthanum is identified by the doublet La $3 d_{5 / 2}-\mathrm{La} 3 d_{3 / 2}$ at $\sim 835$ and $\sim 851 \mathrm{eV}$, respectively, (including relative multiplets with $\triangle$ BEs: $\sim 3.2-3.4 \mathrm{eV}$ ). In the case of $\mathrm{Tb}$ (III), the deconvolution is more difficult due to poorly resolved signals. More specifically, the analysis of the $\mathrm{Tb} 4 d_{5 / 2}$ signal tends to indicate that 
two forms of $\mathrm{Tb}$ may coexist at $\sim 149 \mathrm{eV}$ and $152-151 \mathrm{eV}$; the REE may coexist as bound $\mathrm{Tb}$

(III) but also under its oxidized form, i.e., Tb (IV), respectively [68,69].
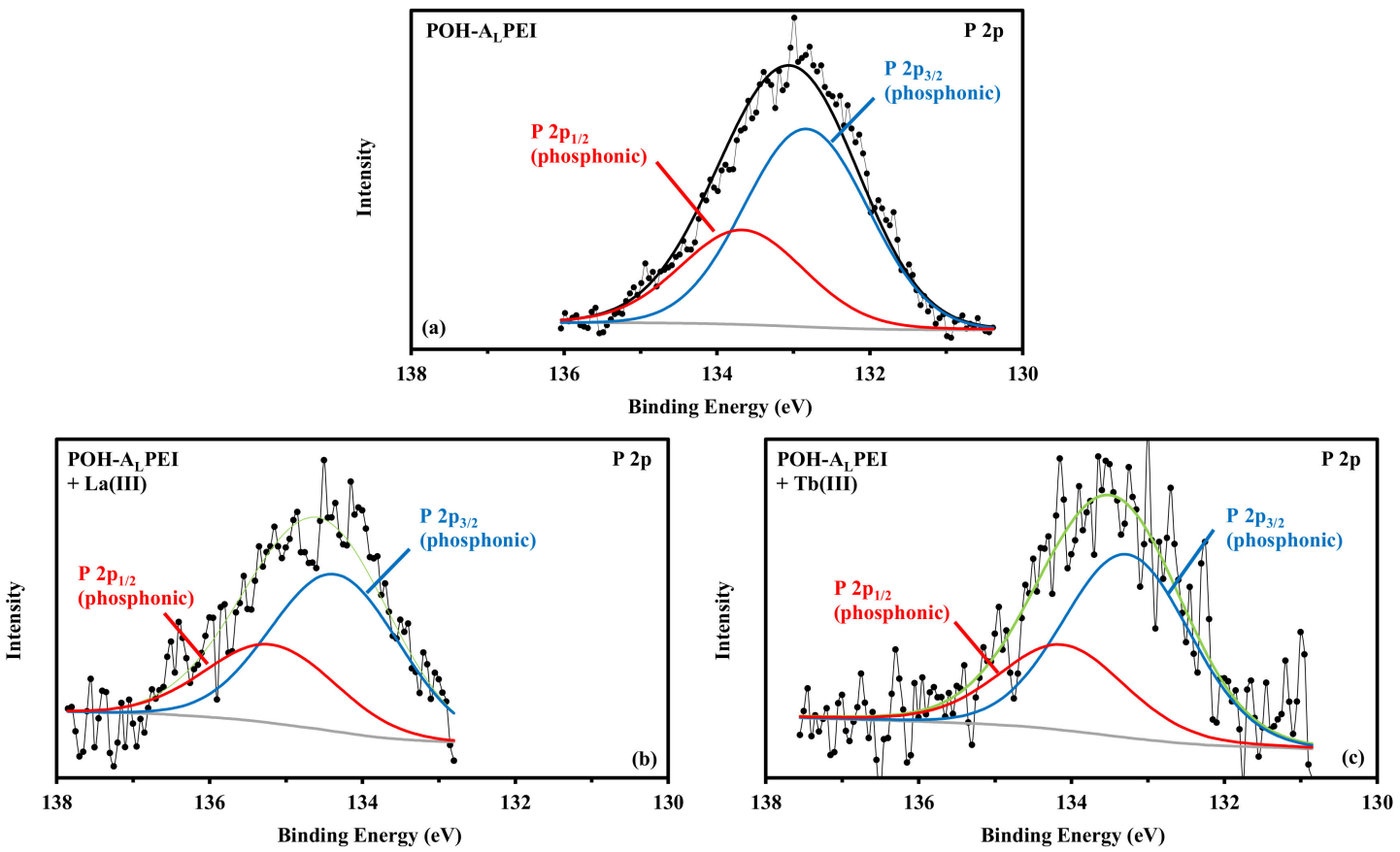

Figure 11. HRES XPS P $2 p$ core level spectra for POH- $\mathrm{A}_{\mathrm{L}}$ PEI before (a) and after metal sorption (La (III): (b); Tb (III): (c)).

\subsubsection{Effect of $\mathrm{pH}$ on $\mathrm{La}$ (III) and $\mathrm{Tb}$ (III) Sorption onto POH-A $\mathrm{L}_{\mathrm{L}} \mathrm{PEI}$}

Figure 12 compares the sorption properties of $\mathrm{La}$ (III) and $\mathrm{Tb}$ (III) for raw and functionalized sorbents. The comparison of the profiles clearly demonstrates the strong improvement in sorption properties associated with the phosphorylation of the sorbent. In the

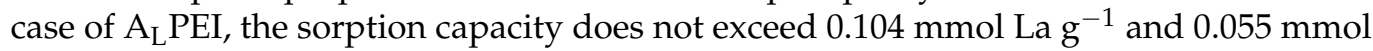
$\mathrm{Tb} \mathrm{g}^{-1}$ in the $\mathrm{pH}$ range $\mathrm{pH}_{0}: 1-5$. On the other hand, the phosphorylation of the beads allows increasing sorption capacities to $0.465 \mathrm{mmol} \mathrm{La} \mathrm{g}^{-1}$ and $0.373 \mathrm{mmol} \mathrm{Tb} \mathrm{g}^{-1}$, under the same experimental conditions. This significant increase $(\times 4.5$ for La and $\times 6.8$ for $\mathrm{Tb})$ may be explained by the increase in the density of reactive groups, their higher affinity for phosphonic groups and the more favorable acid-base characteristics (see $\left.\mathrm{pH}_{\mathrm{PZC}}\right)$. As the $\mathrm{pH}$ increases, the sorption capacities strongly increase for $\mathrm{POH}-\mathrm{A}_{\mathrm{L}} \mathrm{PEI}$ (especially above $\mathrm{pH}_{0} 2$ ), while for $\mathrm{A}_{\mathrm{L}} \mathrm{PEI}$, the effect of $\mathrm{pH}$ is quickly leveled.
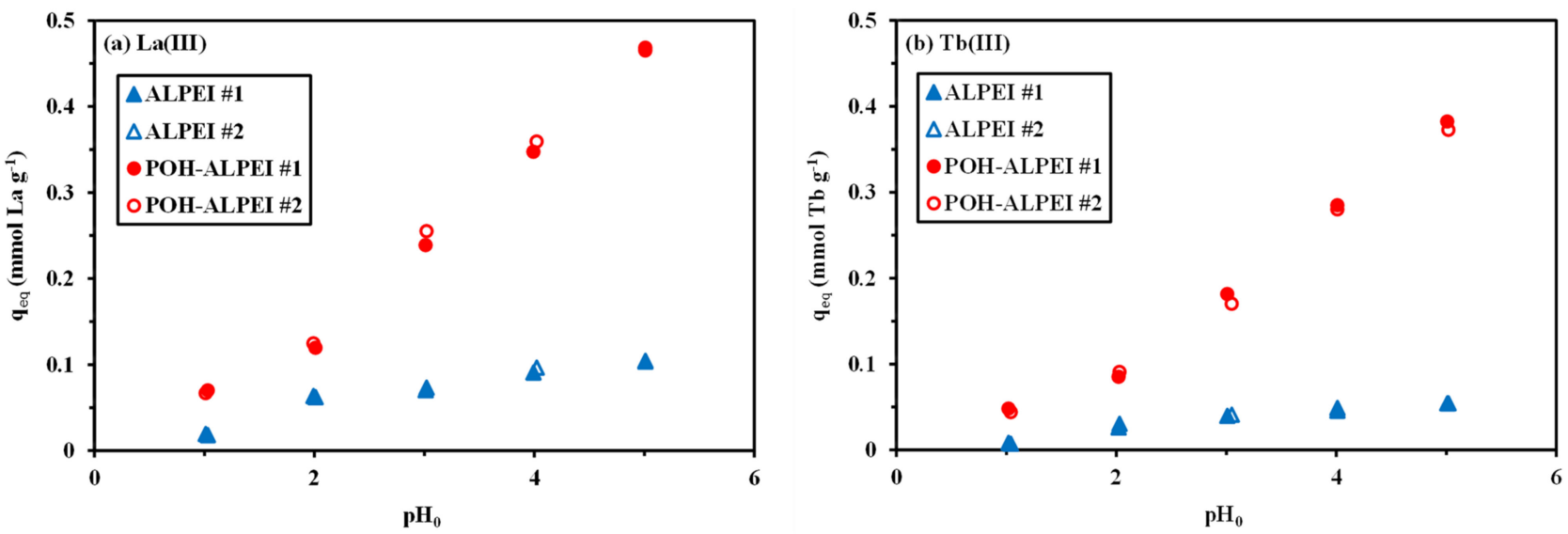

Figure 12. Effect of initial $\mathrm{pH}$ on the sorption of $\mathrm{La}$ (III) (a) and $\mathrm{Tb}$ (III) (b) using $\mathrm{A}_{\mathrm{L}} \mathrm{PEI}$ and POH-A $\mathrm{A}_{\mathrm{L}} \mathrm{PEI}$ sorbents (C $\mathrm{C}_{0}$ : $50 \mathrm{mg} \mathrm{L}^{-1}=0.374 \mathrm{mmol} \mathrm{La} \mathrm{L}^{-1}$ or $0.332 \mathrm{mmol} \mathrm{Tb} \mathrm{L}^{-1}$; Sorbent dose, SD: $0.66 \mathrm{~g} \mathrm{~L}^{-1}$; time: $48 \mathrm{~h}$; $\left.: 21 \pm 1{ }^{\circ} \mathrm{C}\right)$. 
Figure S11 reports the speciation diagrams of lanthanum and terbium under the experimental conditions selected for the study of the $\mathrm{pH}$ effect. The predominant species are $\mathrm{LaSO}_{4}{ }^{+}$and $\mathrm{TbSO}_{4}{ }^{+}$below $\mathrm{pH} 4$; between $\mathrm{pH} 4$ and 6, these species co-exist, at comparable levels, with free $\mathrm{La}^{3+}$ and $\mathrm{Tb}^{3+}$. The anionic metal disulfate species $\left(\mathrm{La}\left(\mathrm{SO}_{4}\right)_{2}{ }^{-}\right.$ and $\mathrm{Tb}\left(\mathrm{SO}_{4}\right)_{2}{ }^{-}$) exist only below $\mathrm{pH} 3$ and never exceed 15-20\%. Throughout the $\mathrm{pH}$ range investigated in this study, the largely predominant species are cationic. Considering that the $\mathrm{pH}_{\mathrm{PZC}}$ of $\mathrm{A}_{\mathrm{L}} \mathrm{PEI}$ is close to 4.29 , the protonation of the sorbent may explain repulsion effects that limit sorption efficiency. Charge repulsion decreases with increasing $\mathrm{pH}$ and enhances metal sorption. However, even at $\mathrm{pH} 2$, the sorption is not negligible. In addition, despite the negative charge of the sorbent at $\mathrm{pH} 5$, the sorption does not increase dramatically. This probably means that the ion-exchange mechanism is not the main reaction pathway. In the case of $\mathrm{POH}-\mathrm{A}_{\mathrm{L}} \mathrm{PEI}$, at $\mathrm{pH}$ below 2.5 , sorption remains very low, below 0.1-0.13 $\mathrm{mmol} \mathrm{g}^{-1}$ (but higher than for $\mathrm{A}_{\mathrm{L}} \mathrm{PEI}$ ). However, at $\mathrm{pH}$ above 2.5, a strong increase in sorption is observed, despite the overall positive charge of the sorbent ( $\mathrm{pH}$ PZC: 6.82). The deprotonation limits the repulsion effect, but this is negligible compared to the strong contribution of new functional groups (phosphonic acid moieties) in the binding of REEs. The binding of metal ions occurs mainly through chelation on phosphonic groups although carboxylate groups (at $\mathrm{pH}$ above $\mathrm{pH} 4$ ) may also contribute, together with some amine groups (limited number of free groups due to the high yield of grafting). Table S10 shows the semi-quantitative EDX analysis of the sorbent after metal sorption at $\mathrm{pH}$ 5. $\mathrm{Cl}$ content is not affected by metal sorption; the sorption of REEs is confirmed by the appearance of $\mathrm{La}(2.64 \%$ weight concentration, $\mathrm{WC}$ ) and $\mathrm{Tb}$ (WC: $3.09 \%)$. Above $\mathrm{pH}$ 6, the formation of hydrolyzed species may cause partial precipitation of the metals.

Figure $\mathrm{S} 12$ reports the $\mathrm{pH}$ changes during metal sorption. It is noteworthy that the highest changes are observed for $\mathrm{POH}-\mathrm{A}_{\mathrm{L}} \mathrm{PEI}$, and more specifically in the $\mathrm{pH}$ range 3-5 (maximum at $\mathrm{pH}$ 4). This is consistent with the titration profiles obtained in the $\mathrm{pH}$-drift method; however, the $\mathrm{pH}$ variations are less marked in the presence of metal ions. It is also remarkable that, in the $\mathrm{pH}$ range $3-4, \mathrm{~A}_{\mathrm{L}} \mathrm{PEI}$ slightly increases the $\mathrm{pH}$, while a reciprocal trend is observed for POH- $\mathrm{A}_{\mathrm{L}} \mathrm{PEI}$. This is another indication of the change in the sorption mechanism for the functionalized sorbent: the release of protons from phosphonic groups (during the sorption of REEs) decreases the $\mathrm{pH}$ (up to 1 unit at $\mathrm{pH}_{0} 4$ ).

\subsubsection{La (III) and $\mathrm{Tb}$ (III) Sorption Mechanisms onto POH-A $\mathrm{A}_{\mathrm{L}} \mathrm{PEI}$}

The combination of the information collected from FTIR and XPS data (shifts of wavenumbers, appearance and disappearance of signals (such as sulfate, $\mathrm{OH}, \mathrm{C}-\mathrm{O}$ and $\mathrm{P}-\mathrm{O})$, changes in the intensity of relevant XPS contributions or appearance of new signals such as $\mathrm{S} 2 p$ ) with acid-base titration ( $\mathrm{pH}_{\mathrm{PZC}}$ ) allows for proposing different mechanisms for metal sorption. These mechanisms may include:

(a) Ion exchange of REE cation with $\mathrm{Ca}^{2+}$ bonded to carboxylic groups (resulting from ionotropic gelation, confirmed by $\mathrm{Ca}^{2+}$ disappearance on XPS spectra), and/or with protons from protonated amine groups and from hydroxyl groups $(\mathrm{pH}$ decrease after metal sorption).

(b) Chelation mechanism on the electron doublet of nitrogen from amines groups, hydroxyls from polysaccharides, or from grafted phosphate groups.

The metal binding may occur through the uptake of trivalent metals or sulfate species (as shown by speciation diagram and both FTIR and XPS analyses). Scheme 2 shows the binding mechanisms potentially involved in metal binding. 


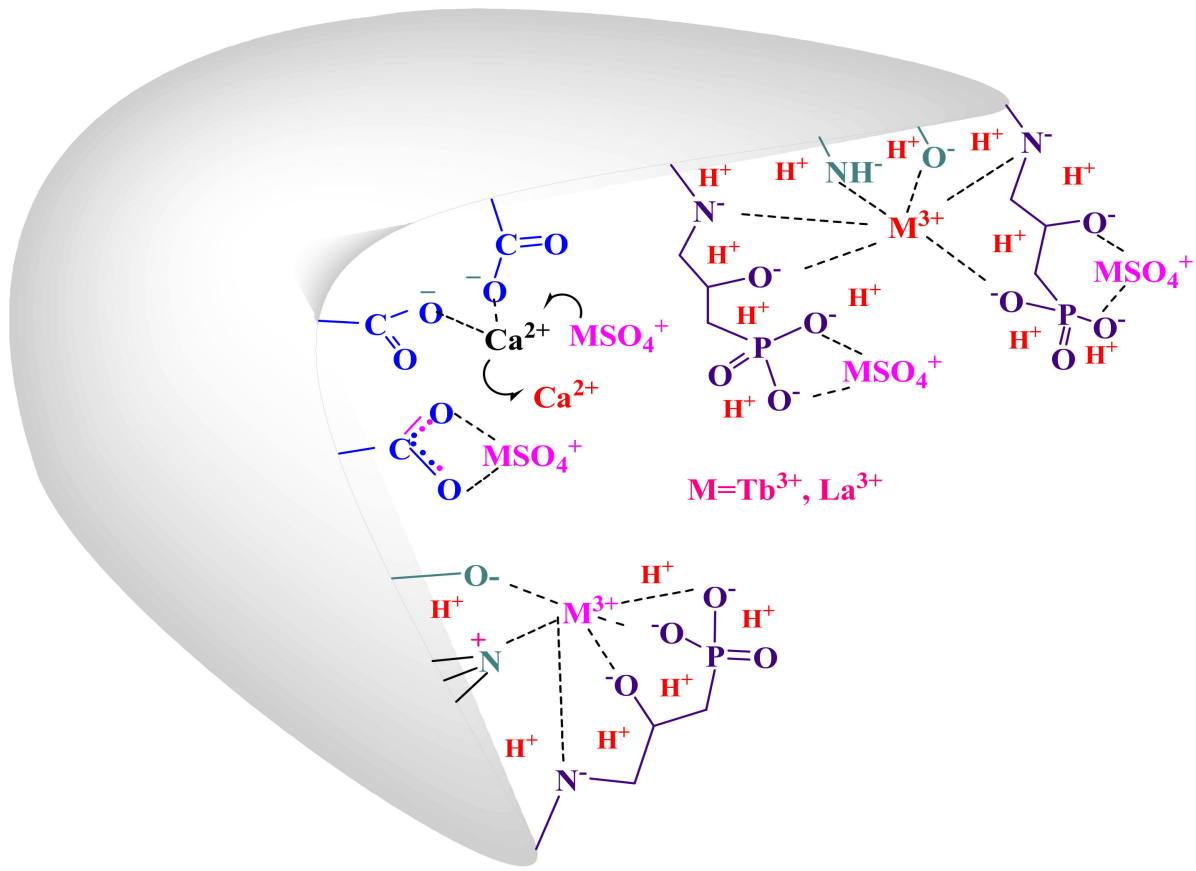

Scheme 2. Tentative mechanisms for the sorption of $\mathrm{La}$ (III) and $\mathrm{Tb}(\mathrm{III})$ onto POH- $\mathrm{A}_{\mathrm{L}}$ PEI.

\section{Conclusions and Perspectives}

This preliminary study focuses on the design of a new functionalization method of algal biomass/polyethylenimine composite: the activation of the sorbent with epichlorohydrin followed by the phosphorylation of the activated material and its de-esterification. The chemical modifications are followed using FTIR and XPS spectroscopic methods not only to identify changes in chemical groups but also to interpret the binding mechanisms involved in the uptake of two rare earth elements in mild acidic solutions ( $\mathrm{pH}$ close to 4). In combination with TGA characterization, elemental analysis, and titration (for the determination of $\mathrm{pH}_{\mathrm{PZC}}$ values), it is possible to correlate chemical functionalization with remarkable sorption properties of the new sorbent. Sorption of rare earth elements (at least, partially in the form of sulfate complexes), which increases with $\mathrm{pH}$, involves contributions from amine, hydroxyl, carboxylate and phosphonate groups (in relation with the multifunctional composition of the composite). FTIR analysis confirms the remarkable stability of the sorbent after being subjected to five cycles of sorption and desorption (using acidic calcium chloride solution).

Under the experimental conditions selected for this study, the sorption capacity of the functionalized sorbent is increased 4.5 times for La (III) and up to 6.9 times for Tb (III), compared with raw support. This remarkable enhancement in sorption properties clearly justifies further investigation of the sorption properties of this new sorbent. A complementary study is currently being investigated focusing on the sorption of these two metal ions including uptake kinetics, sorption isotherms, metal desorption kinetics, effective recycling and selectivity in synthetic solutions. In this companion work, the sorbent is also considered as part of the global treatment of an Egyptian ore. This complementary study includes: acidic heap leaching, sorption on quaternary ammonium resin, sorption on $\mathrm{POH}-\mathrm{A}_{\mathrm{L}} \mathrm{PEI}$, metal desorption from functionalized sorbent, oxalic acid precipitation for selective recovery of REEs and successive precipitations of the residue for separation of iron and aluminum and final recovery of uranium.

Sorbents loaded with rare earth elements (typically with lanthanum) have been successively used for the removal of phosphorous from aqueous effluents [70-72]. This may be an interesting field for the application of these new materials. 
Supplementary Materials: The following are available online at https: / www.mdpi.com/article/ 10.3390/polym13091513/s1. Table S1. Optical micrographs for ALPEI, POH-ALPEI (and average bead size); Table S2. SEM micrographs of $A_{L} P E I, C l-A_{L} P E I, P-A_{L} P E I$ and POH- $A_{L}$ PEI; Table S3. Semi-quantitative EDX analysis of surface and crosscut section of $A_{L} P E I, C l-A_{L}$ PEI, P-A $A_{L} P E I$ and POH-A $A_{L}$ PEI; Table S4. Elemental analysis of $A_{L}$ PEI beads, intermediary products (epichlorohydrinactivated $A_{L}$ PEI, Cl- $A_{L}$ PEI and phosphorylated $A_{L}$ PEI beads, $P^{*}-A_{L} P E I$ ) and sorbent (de-esterified phosphorylated beads, POH-A $\mathrm{L}$ PEI); Table S5. FTIR assignments and wavenumbers $\left(\mathrm{cm}^{-1}\right)$ of $\mathrm{A}_{\mathrm{L}} \mathrm{PEI}$, intermediary products (epichlorohydrin-activated $\mathrm{A}_{\mathrm{L}} \mathrm{PEI}, \mathrm{Cl}-\mathrm{A}_{\mathrm{L}} \mathrm{PEI}$ and phosphorylated $A_{L}$ PEI beads, $P^{*}-A_{L} P E I$ ) and sorbent (de-esterified phosphorylated beads, $\mathrm{POH}-\mathrm{A}_{\mathrm{L}} \mathrm{PEI}$ ); Table $\mathrm{S6}$. Assignments and interpretation of major XPS signals for $A_{L} P E I$, intermediary products (i.e., $\mathrm{Cl}-\mathrm{A}_{\mathrm{L}} \mathrm{PEI}$ and $\left.\mathrm{P}^{*}-\mathrm{A}_{\mathrm{L}} \mathrm{PEI}\right)$ and P2-A $\mathrm{A}_{\mathrm{L}}$ PEI; Table S7. FTIR assignments and wavenumbers $\left(\mathrm{cm}^{-1}\right)$ of $\mathrm{A}_{\mathrm{L}}$ PEI before and after $\mathrm{La}$ (III) and $\mathrm{Tb}$ (III) (and after 5 cycles of sorption/desorption); Table S8. FTIR assignments and wavenumbers $\left(\mathrm{cm}^{-1}\right)$ of POH-A $\mathrm{A}_{\mathrm{L}}$ PEI before and after $\mathrm{La}$ (III) and Tb (III) (and after 5 cycles of sorption desorption); Table S9. Assignments and interpretation of major XPS signals for POH-A $A_{L} P E I$ before and after $\mathrm{La}$ (III) and Tb (III) sorption; Table S10. SEM micrographs and semi-quantitative EDX analysis of surface of $\mathrm{POH}-\mathrm{A}_{\mathrm{L}} \mathrm{PEI}$ after $\mathrm{La}$ (III) and $\mathrm{Tb}$ (III) sorption at $\mathrm{pH}_{0} 5$; Figure S1. Thermal degradation of $A_{L}$ PEI beads, intermediary products (epichlorohydrin-activated $A_{L} P E I, C l-A_{L} P E I$ and phosphorylated $\mathrm{A}_{\mathrm{L}} \mathrm{PEI}$ beads, $\mathrm{P}^{*}-\mathrm{A}_{\mathrm{L}} \mathrm{PEI}$ ) and sorbent (de-esterified phosphorylated beads, $\mathrm{POH}-$ $\mathrm{A}_{\mathrm{L}} \mathrm{PEI}$ ): (a) TGA and (b) DrTG; Figure S2. Determination of the $\mathrm{pH}_{\mathrm{PZC}}$ of $\mathrm{A}_{\mathrm{L}}$ PEI and POH-A $\mathrm{AEI}$ sorbents using the $\mathrm{pH}$ drift method (Sorbent dosage, SD: $2 \mathrm{~g} \mathrm{~L}^{-1}$; time: $48 \mathrm{~h}$; background salt: $0.1 \mathrm{M}$ $\mathrm{NaCl}$ ); Figure S3. Focused FTIR spectra of $\mathrm{A}_{\mathrm{L}} \mathrm{PEI}, \mathrm{POH}-\mathrm{A}_{\mathrm{L}} \mathrm{PEI}$ and intermediary products; Figure S4. HRES XPS C $1 s, \mathrm{O} 1 s, \mathrm{~N} 1 s$ and S $2 p$ core level spectra for $\mathrm{A}_{\mathrm{L}}$ PEI; Figure S5. HRES XPS C 1s, O $1 s$, $\mathrm{N} 1 s, \mathrm{~S} 2 p$ and $\mathrm{Cl} 2 p$ core level spectra for Cl-A $\mathrm{A}_{\mathrm{L}} \mathrm{PEI}$; Figure S6. HRES XPS C $1 s, \mathrm{O} 1 s, \mathrm{~N} 1 s, \mathrm{P} 2 p, \mathrm{~S}$ $2 p$ and $\mathrm{Cl} 2 p$ core level spectra for POH-A $\mathrm{PEI}$; Figure S7. HRES XPS C $1 s, \mathrm{O} 1 s, \mathrm{~N} 1 s, \mathrm{P} 2 p, \mathrm{Cl} 2 p$ and S $2 p$ core level spectra for POH-A $\mathrm{A}_{\mathrm{L}} \mathrm{PEI}$; Figure S8. HRES XPS Ca $2 p$ core level spectra for $\mathrm{A}_{\mathrm{L}} \mathrm{PEI}$, $\mathrm{Cl}-\mathrm{A}_{\mathrm{L}} \mathrm{PEI}, \mathrm{P}^{*}-\mathrm{A}_{\mathrm{L}} \mathrm{PEI}$ and POH-A $\mathrm{A}$ PEI; Figure S9. HRES XPS C $1 s, \mathrm{O} 1 s, \mathrm{~N} 1 s, \mathrm{P} 2 p, \mathrm{~S} 2 p$ and La $3 d$ core level spectra for POH-A $\mathrm{L}_{\mathrm{PEI}}$ after La (III) sorption; Figure S10. HRES XPS C 1s, O 1s, N 1s, P $2 p, \mathrm{~S} 2 p$ and $\mathrm{Tb} 4 d$ core level spectra for $\mathrm{POH}-\mathrm{A}_{\mathrm{L}} \mathrm{PEI}$ after $\mathrm{Tb}$ (III) sorption; Figure $\mathrm{S} 11$. Speciation diagrams for $\mathrm{La}$ (III) and $\mathrm{Tb}$ (III) (under experimental conditions corresponding to the study of $\mathrm{pH}$ effect: $\mathrm{C}_{0}$ : $0.372 \mathrm{mmol} \mathrm{La} \mathrm{L}^{-1}$ and $0.334 \mathrm{mmol} \mathrm{Tb} \mathrm{L}^{-1}$ ); Figure S12. $\mathrm{pH}$ variation during La (III) (a) and $\mathrm{Tb}(\mathrm{III})(\mathrm{b})$ sorption using $\mathrm{A}_{\mathrm{L}}$ PEI and POH-A $\mathrm{L}$ PEI sorbents $\left(\mathrm{C}_{0}: 50 \mathrm{mg} \mathrm{L}^{-1}=0.374 \mathrm{mmol} \mathrm{La} \mathrm{L}^{-1}\right.$ or $0.332 \mathrm{mmol} \mathrm{Tb} \mathrm{L}{ }^{-1}$; Sorbent dosage, SD: $0.66 \mathrm{~g} \mathrm{~L}^{-1}$; time: $48 \mathrm{~h}$; $\mathrm{T}: 21 \pm 1{ }^{\circ} \mathrm{C}$ ).

Author Contributions: Conceptualization, Y.W., M.F.H. and E.G.; methodology and software, E.R.C., T.F. and E.G.; validation, Y.W. and E.G.; formal analysis, K.A.M.S., T.F. and M.F.H.; investigation, Y.W. and M.F.H.; resources, E.R.-C. and K.A.M.S.; data curation, K.A.M.S., T.F. and E.G.; writingoriginal draft preparation, E.G. and M.F.H.; writing—review and editing, E.R.-C., E.G. and M.F.H.; visualization, T.F., M.F.H. and E.G.; supervision, Y.W. and M.F.H.; project administration, Y.W.; funding acquisition, Y.W. and E.R.-C. All authors have read and agreed to the published version of the manuscript.

Funding: Y.W. thanks the support of NSFC (National Natural Science Foundation of China) Projects (No. 11975082, U1967218) and Science and Technology Major Project of Guangxi Province (China) (AA17204100, AA18118030). E.G., and M.F.H., acknowledge Institut Français d’Egypte and Egyptian Academy of Science and Technology, Egypt for supporting the collaboration between IMT-Mines Ales and Nuclear Materials Authority, through IMHOTEP project "MetalValor" (ref. 39529QA). E.R.-C. thanks the project RTI2018-099668-BC22 of Ministerio de Ciencia, Innovación y Universidades, the project UMA18-FEDERJA-126 of Junta de Andalucía and FEDER funds.

Data Availability Statement: Data are available from corresponding authors.

Conflicts of Interest: The authors declare no conflict of interest.

\section{References}

1. Buechler, D.T.; Zyaykina, N.N.; Spencer, C.A.; Lawson, E.; Ploss, N.M.; Hua, I. Comprehensive elemental analysis of consumer electronic devices: Rare earth, precious, and critical elements. Waste Manag. 2019, 103, 67-75. [CrossRef] [PubMed]

2. Zhang, B.; Liu, C.; Li, C.; Jiang, M. Separation and recovery of valuable metals from low-grade REE-Nb-Fe ore. Int. J. Miner. Process. 2016, 150, 16-23. [CrossRef] 
3. Wu, S.; Wang, L.; Zhao, L.; Zhang, P.; El-Shall, H.; Moudgil, B.; Huang, X.; Zhang, L. Recovery of rare earth elements from phosphate rock by hydrometallurgical processes-A critical review. Chem. Eng. J. 2018, 335, 774-800. [CrossRef]

4. Balaram, V. Rare earth elements: A review of applications, occurrence, exploration, analysis, recycling, and environmental impact. Geosci. Front. 2019, 10, 1285-1303. [CrossRef]

5. Sethurajan, M.; van Hullebusch, E.D.; Fontana, D.; Akcil, A.; Deveci, H.; Batinic, B.; Leal, J.P.; Gasche, T.A.; Kucuker, M.A.; Kuchta, K.; et al. Recent advances on hydrometallurgical recovery of critical and precious elements from end of life electronic wastes-A review. Crit. Rev. Environ. Sci. Technol. 2019, 49, 212-275. [CrossRef]

6. Swain, N.; Mishra, S. A review on the recovery and separation of rare earths and transition metals from secondary resources. J. Cleaner Prod. 2019, 220, 884-898. [CrossRef]

7. Spooren, J.; Atia, T.A. Combined microwave assisted roasting and leaching to recover platinum group metals from spent automotive catalysts. Miner. Eng. 2020, 146, 106153. [CrossRef]

8. Asadollahzadeh, M.; Torkaman, R.; Torab-Mostaedi, M.; Hemmati, A.; Ghaemi, A. Efficient recovery of neodymium and praseodymium from $\mathrm{NdFeB}$ magnet-leaching phase with and without ionic liquid as a carrier in the supported liquid membrane. Chem. Pap. 2020, 74, 4193-4201. [CrossRef]

9. Wu, S.; Zhao, L.; Wang, L.; Huang, X.; Zhang, Y.; Feng, Z.; Cui, D. Simultaneous recovery of rare earth elements and phosphorus from phosphate rock by phosphoric acid leaching and selective precipitation: Towards green process. J. Rare Earths 2019, 37, 652-658. [CrossRef]

10. Virolainen, S.; Repo, E.; Sainio, T. Recovering rare earth elements from phosphogypsum using a resin-in-leach process: Selection of resin, leaching agent, and eluent. Hydrometallurgy 2019, 189, 105125. [CrossRef]

11. Pavon, S.; Fortuny, A.; Call, M.T.; Sastre, A.M. Improved rare earth elements recovery from fluorescent lamp wastes applying supported liquid membranes to the leaching solutions. Sep. Purif. Technol. 2019, 224, 332-339. [CrossRef]

12. Artiushenko, O.; Zaitsev, V.; Rojano, W.S.; Freitas, G.A.; Nazarkovsky, M.; Saint'Pierre, T.D.; Kai, J. Rationally designed dipicolinate-functionalized silica for highly efficient recovery of rare-earth elements from e-waste. J. Hazard. Mater. 2021, 408, 124976. [CrossRef]

13. Huang, L.; Liu, L.; Huang, W.; Zhao, B.; Shen, Z.; Bao, Y.; Znad, H. Recovery of lanthanum cations by functionalized magnetic multi-walled carbon nanotube bundles. RSC Adv. 2021, 11, 4751-4759. [CrossRef]

14. Hua, W.; Zhang, T.; Ding, S.; Wang, X. A novel cost-effective PAN/CNS nanofibrous membranes with rich carboxyl groups for high efficient adsorption of Lanthanum (III) ions. Sep. Purif. Technol. 2021, 259, 118216. [CrossRef]

15. Moghzi, F.; Soleimannejad, J.; Sanudo, E.C.; Janczak, J. Sensitizing, sensing and chemical separation of Tb (III) ions: All in a novel copper metal-organic framework. Mater. Res. Bull. 2020, 122, 110683. [CrossRef]

16. Madbouly, H.A.; El-Hefny, N.E.; El-Nadi, Y.A. Adsorption and separation of terbium (III) and gadolinium (III) from aqueous nitrate medium using solid extractant. Sep. Sci. Technol. 2021, 56, 681-693. [CrossRef]

17. Botelho, A.B., Jr.; Pinheiro, E.F.; Espinosa, D.C.R.; Tenorio, J.A.S.; Baltazar, M.d.P.G. Adsorption of lanthanum and cerium on chelating ion exchange resins: Kinetic and thermodynamic studies. Sep. Sci. Technol. 2021. [CrossRef]

18. Ni'am, A.C.; Wang, Y.-F.; Chen, S.-W.; Chang, G.-M.; You, S.-J. Simultaneous recovery of rare earth elements from waste permanent magnets (WPMs) leach liquor by solvent extraction and hollow fiber supported liquid membrane. Chem. Eng. Process. Process Intensif. 2020, 148, 107831. [CrossRef]

19. Pavon, S.; Fortuny, A.; Coll, M.T.; Sastre, A.M. Solvent extraction modeling of Ce/Eu/Y from chloride media using D2EHPA. AIChE J. 2019, 65, e16627. [CrossRef]

20. Pavon, S.; Fortuny, A.; Coll, M.T.; Sastre, A.M. Neodymium recovery from NdFeB magnet wastes using Primene 81 R.Cyanex 572 IL by solvent extraction. J. Environ. Manag. 2018, 222, 359-367. [CrossRef]

21. Xia, Y.; Xiao, L.; Tian, J.; Li, Z.; Zeng, L. Recovery of rare earths from acid leach solutions of spent nickel-metal hydride batteries using solvent extraction. J. Rare Earths 2015, 33, 1348-1354. [CrossRef]

22. Jorjani, E.; Shahbazi, M. The production of rare earth elements group via tributyl phosphate extraction and precipitation stripping using oxalic acid. Arab. J. Chem. 2016, 9, S1532-S1539. [CrossRef]

23. Sinha, S.; Abhilash; Meshram, P.; Pandey, B.D. Metallurgical processes for the recovery and recycling of lanthanum from various resources-A review. Hydrometallurgy 2016, 160, 47-59. [CrossRef]

24. Abisheva, Z.S.; Karshigina, Z.B.; Bochevskaya, Y.G.; Akcil, A.; Sargelova, E.A.; Kvyatkovskaya, M.N.; Silachyov, I.Y. Recovery of rare earth metals as critical raw materials from phosphorus slag of long-term storage. Hydrometallurgy 2017, 173, 271-282. [CrossRef]

25. Hidayah, N.N.; Abidin, S.Z. The evolution of mineral processing in extraction of rare earth elements using liquid-liquid extraction: A review. Miner. Eng. 2018, 121, 146-157. [CrossRef]

26. Wu, S.; Wang, L.; Zhang, P.; El-Shall, H.; Moudgil, B.; Huang, X.; Zhao, L.; Zhang, L.; Feng, Z. Simultaneous recovery of rare earths and uranium from wet process phosphoric acid using solvent extraction with D2EHPA. Hydrometallurgy 2018, 175, 109-116. [CrossRef]

27. Hou, H.; Xu, J.; Wang, Y.; Chen, J. Solvent extraction of lanthanum and cerium ions from hydrochloric acidic aqueous solutions using partly saponified 2-ethylhexyl phosphonic acid mono-2-ethylhexyl ester. Chin. J. Chem. Eng. 2016, 24, 79-85. [CrossRef]

28. Huang, X.; Dong, J.; Wang, L.; Feng, Z.; Xue, Q.; Meng, X. Selective recovery of rare earth elements from ion-adsorption rare earth element ores by stepwise extraction with HEH(EHP) and HDEHP. Green Chem. 2017, 19, 1345-1352. [CrossRef] 
29. Singh, D.K.; Anitha, M.; Kain, V. Development of solvent extraction process for erbium purification. Sep. Sci. Technol. 2017, 52, 2284-2290. [CrossRef]

30. Tunsu, C.; Petranikova, M.; Ekberg, C.; Retegan, T. A hydrometallurgical process for the recovery of rare earth elements from fluorescent lamp waste fractions. Sep. Purif. Technol. 2016, 161, 172-186. [CrossRef]

31. Rho, B.-J.; Sun, P.-P.; Cho, S.-Y. Recovery of neodymium and praseodymium from nitrate-based leachate of permanent magnet by solvent extraction with trioctylphosphine oxide. Sep. Purif. Technol. 2020, 238, 116429. [CrossRef]

32. Pavon, S.; Fortuny, A.; Coll, M.T.; Sastre, A.M. Rare earths separation from fluorescent lamp wastes using ionic liquids as extractant agents. Waste Manag. 2018, 82, 241-248. [CrossRef]

33. Erust, C.; Akcil, A.; Tuncuk, A.; Deveci, H.; Yazici, E.Y. A multi-stage process for recovery of neodymium (Nd) and dysprosium (Dy) from spent hard disc drives (HDDs). Miner. Process. Extr. Metall. Rev. 2019, 42, 99-101. [CrossRef]

34. Reddy, B.R.; Kumar, J.R. Rare earths extraction, separation, and recovery from phosphoric acid media. Solvent Extr. Ion Exch. 2016, 34, 226-240. [CrossRef]

35. Agarwal, V.; Safarzadeh, M.S. Solvent extraction and separation of cerium (III) and samarium (III) from mixed rare earth solutions using PC88A. Miner. Metall. Process. 2017, 34, 125-131. [CrossRef]

36. Sharaf, M.; Yoshida, W.; Kubota, F.; Goto, M. Selective extraction of scandium by a long alkyl chain carboxylic acid/organophosphonic ester binary extractant. Solvent Extr. Ion Exch. 2018, 36, 647-657. [CrossRef]

37. Gomes, R.D.; Seruff, L.A.; Waineraich Scal, M.L.; Vera, Y.M. The Influence of lactic acid concentration on the separation of light rare earth elements by continuous liquid-liquid extraction with 2-ethylhexyl phosphonic acid mono-2-ethylhexyl ester. Metall. Mater. Trans. B 2018, 49, 460-465. [CrossRef]

38. Kumar, B.N.; Radhika, S.; Kantam, M.L.; Reddy, B.R. Solid-liquid extraction of terbium from phosphoric acid solutions using solvent-impregnated resin containing TOPS 99. J. Chem. Technol. Biotechnol. 2011, 86, 562-569. [CrossRef]

39. Kumar, B.N.; Radhika, S.; Reddy, B.R. Solid-liquid extraction of heavy rare-earths from phosphoric acid solutions using Tulsion CH-96 and T-PAR resins. Chem. Eng. J. 2010, 160, 138-144. [CrossRef]

40. Araucz, K.; Aurich, A.; Kolodynska, D. Novel multifunctional ion exchangers for metal ions removal in the presence of citric acid. Chemosphere 2020, 251, 126331. [CrossRef]

41. De Decker, J.; de Clercq, J.; Vermeir, P.; van der Voort, P. Functionalized metal-organic-framework CMPO@MIL-101(Cr) as a stable and selective rare earth adsorbent. J. Mater. Sci. 2016, 51, 5019-5026. [CrossRef]

42. Heres, X.; Blet, V.; Di Natale, P.; Ouaattou, A.; Mazouz, H.; Dhiba, D.; Cuer, F. Selective extraction of rare earth elements from phosphoric acid by ion exchange resins. Metals 2018, 8, 8090682. [CrossRef]

43. Imam, E.A.; El-Tantawy El-Sayed, I.; Mahfouz, M.G.; Tolba, A.A.; Akashi, T.; Galhoum, A.A.; Guibal, E. Synthesis of $\alpha-$ aminophosphonate functionalized chitosan sorbents: Effect of methyl vs. phenyl group on uranium sorption. Chem. Eng. J. 2018, 352, 1022-1034. [CrossRef]

44. Rashad, M.M.; El-Sayed, I.E.; Galhoum, A.A.; Abdeen, M.M.; Mira, H.I.; Elshehy, E.A.; Zhang, S.; Lu, X.; Xin, J.; Guibal, E. Synthesis of $\alpha$-aminophosphonate based sorbents - Influence of inserted groups (carboxylic vs. amine) on uranyl sorption. Chem. Eng. J. 2021, 127830. [CrossRef]

45. Lapo, B.; Bou, J.J.; Hoyo, J.; Carrillo, M.; Pena, K.; Tzanov, T.; Sastre, A.M. A potential lignocellulosic biomass based on banana waste for critical rare earths recovery from aqueous solutions. Environ. Pollut. 2020, 264, 114409. [CrossRef]

46. Javadian, H.; Ruiz, M.; Taghavi, M.; Sastre, A.M. Synthesis of magnetic CMC bionanocomposite containing a novel biodegradable nanoporous polyamide selectively synthesized in ionic liquid as green media: Investigation on $\mathrm{Nd}^{+3}, \mathrm{~Tb}^{+3}$, and $\mathrm{Dy}^{+3}$ rare earth elements adsorption. J. Mol. Liq. 2020, 308, 113017. [CrossRef]

47. Hamza, M.F.; Lu, S.M.; Salih, K.A.M.; Mira, H.; Dhmees, A.S.; Fujita, T.; Wei, Y.Z.; Vincent, T.; Guibal, E. As(V) sorption from aqueous solutions using quaternized algal/polyethyleneimine composite beads. Sci. Total Environ. 2020, 719, 137396. [CrossRef]

48. Hamza, M.F.; Salih, K.A.M.; Abdel-Rahman, A.A.H.; Zayed, Y.E.; Wei, Y.; Liang, J.; Guibal, E. Sulfonic-functionalized algal/PEI beads for scandium, cerium and holmium sorption from aqueous solutions (synthetic and industrial samples). Chem. Eng. J. 2021, 403, 126399. [CrossRef]

49. Wei, Y.; Salih, K.A.M.; Rabie, K.; Elwakeel, K.Z.; Zayed, Y.E.; Hamza, M.F.; Guibal, E. Development of phosphoryl-functionalized algal-PEI beads for the sorption of $\mathrm{Nd}$ (III) and Mo (VI) from aqueous solutions - Application for rare earth recovery from acid leachates. Chem. Eng. J. 2021, 127399. [CrossRef]

50. Maia, M.T.; Sena, D.N.; Calais, G.B.; Luna, F.M.T.; Beppu, M.M.; Vieira, R.S. Effects of histidine modification of chitosan microparticles on metal ion adsorption. React. Funct. Polym. 2020, 154, 104694. [CrossRef]

51. Lopez-Ramon, M.V.; Stoeckli, F.; Moreno-Castilla, C.; Carrasco-Marin, F. On the characterization of acidic and basic surface sites on carbons by various techniques. Carbon 1999, 37, 1215-1221. [CrossRef]

52. Xiao, F.; Wu, K.; Luo, F.; Guo, Y.; Zhang, S.; Du, X.; Zhu, Q.; Lu, M. An efficient phosphonate-based ionic liquid on flame retardancy and mechanical property of epoxy resin. J. Mater. Sci. 2017, 52, 13992-14003. [CrossRef]

53. Kolodynska, D.; Fila, D.; Hubicki, Z. Static and dynamic studies of lanthanum (III) ion adsorption/desorption from acidic solutions using chelating ion exchangers with different functionalities. Environ. Res. 2020, 191, 110171. [CrossRef] [PubMed]

54. Glowinska, A.; Trochimczuk, A.W. Polymer-supported phosphoric, phosphonic and phosphinic acids-From synthesis to properties and applications in separation processes. Molecules 2020, 25, 25184236. [CrossRef] 
55. Fertah, M.; Belfkira, A.; Dahmane, E.M.; Taourirte, M.; Brouillette, F. Extraction, and characterization of sodium alginate from Moroccan Laminaria digitata brown seaweed. Arab. J. Chem. 2017, 10, S3707-S3714. [CrossRef]

56. Allahgholi, L.; Sardari, R.R.R.; Hakvag, S.; Ara, K.Z.G.; Kristjansdottir, T.; Aasen, I.M.; Fridjonsson, O.H.; Brautaset, T.; Hreggvidsson, G.O.; Karlsson, E.N. Composition analysis and minimal treatments to solubilize polysaccharides from the brown seaweed Laminaria digitata for microbial growth of thermophiles. J. Appl. Phycol. 2020, 32, 1933-1947. [CrossRef]

57. Manns, D.; Nielsen, M.; Bruhn, A.; Saake, B.; Meyer, A. Compositional variations of brown seaweeds Laminaria digitata and Saccharina latissima in Danish waters. J. Appl. Phycol. 2017, 29, 1493-1506. [CrossRef]

58. Coates, J. Interpretation of Infrared Spectra, A Practical Approach. In Encyclopedia of Analytical Chemistry; John Wiley \& Sons, Ltd.: Hoboken, NJ, USA, 2006; pp. 1-23.

59. Kuo, P.-Y.; Sain, M.; Yan, N. Synthesis and characterization of an extractive-based bio-epoxy resin from beetle infested Pinus contorta bark. Green Chem. 2014, 16, 3483-3493. [CrossRef]

60. Mallard, I.; Landy, D.; Fourmentin, S. Evaluation of polyethylene glycol crosslinked $\beta$-CD polymers for the removal of methylene blue. Appl. Sci. 2020, 10, 10134679. [CrossRef]

61. Zenobi, M.C.; Luengo, C.V.; Avena, M.J.; Rueda, E.H. An ATR-FTIR study of different phosphonic acids in aqueous solution. Spectrochim. Acta Part A 2008, 70, 270-276. [CrossRef]

62. Zenobi, M.C.; Luengo, C.V.; Avena, M.J.; Rueda, E.H. An ATR-FTIR study of different phosphonic acids adsorbed onto boehmite. Spectrochim. Acta Part A 2010, 75, 1283-1288. [CrossRef]

63. Illy, N.; Couture, G.; Auvergne, R.; Caillol, S.; David, G.; Boutevin, B. New prospects for the synthesis of N-alkyl phosphonate/phosphonic acid-bearing oligo-chitosan. RSC Adv. 2014, 4, 24042-24052. [CrossRef]

64. Son, D.; Cho, S.; Nam, J.; Lee, H.; Kim, M. X-ray-based spectroscopic techniques for characterization of polymer nanocomposite materials at a molecular level. Polymers 2020, 12, 12051053. [CrossRef]

65. Abate, S.Y.; Huang, D.-C.; Tao, Y.-T. Surface modification of $\mathrm{TiO}_{2}$ layer with phosphonic acid monolayer in perovskite solar cells: Effect of chain length and terminal functional group. Org. Electron. 2020, 78, 105583. [CrossRef]

66. Ivan Hernandez-Velazquez, P.; Gutierrez-Ortega, J.A.; Guadalupe Carbajal-Arizaga, G.; Manriquez-Gonzalez, R.; De la CruzHernandez, W.; Gomez-Salazar, S. Hybrid functionalized phosphonate silica: Insight into chromium removal chemistry from aqueous solutions. J. Mex. Chem. Soc. 2019, 63, 130-153. [CrossRef]

67. Giannakoudakis, D.A.; Anastopoulos, I.; Barczak, M.; Alphantoniou, E.; Terpilowski, K.; Mohammadi, E.; Shams, M.; Coy, E.; Bakandritsos, A.; Katsoyiannis, I.A.; et al. Enhanced uranium removal from acidic wastewater by phosphonate-functionalized ordered mesoporous silica: Surface chemistry matters the most. J. Hazard. Mater. 2021, 413, 125279. [CrossRef]

68. Glätzle, M.; Janka, O.; Svitlyk, V.; Chernyshov, D.; Bartsch, M.; Zacharias, H.; Pöttgen, R.; Huppertz, H. The high-pressure oxide $\mathrm{Tb}_{3} \mathrm{O}_{5}$ and its non-centrosymmetric low-temperature polymorph-A comprehensive study. Chemistry 2018, 24, 15236-15245. [CrossRef]

69. Ahmad, I.; Akhtar, M.S.; Ahmed, E.; Ahmad, M.; Keller, V.; Khan, W.Q.; Khalid, N.R. Rare earth co-doped ZnO photocatalysts: Solution combustion synthesis and environmental applications. Sep. Purif. Technol. 2020, 237, 12. [CrossRef]

70. Wang, X.; Liu, Z.; Liu, J.; Huo, M.; Huo, H.; Yang, W. Removing phosphorus from aqueous solutions using lanthanum modified pine needles. PLoS One 2015, 10, e0142700. [CrossRef]

71. Zhou, A.J.; Zhu, C.; Chen, W.W.; Wan, J.; Tao, T.; Zhang, T.C.; Xie, P.C. Phosphorus recovery from water by lanthanum hydroxide embedded interpenetrating network poly (vinyl alcohol)/sodium alginate hydrogel beads. Colloids Surf. A 2018, 554, 237-244. [CrossRef]

72. Park, Y.; Gorman, C.; Ford, E. Lanthanum carbonate nanofibers for phosphorus removal from water. J. Mater. Sci. 2020, 55, 5008-5020. [CrossRef] 